\title{
Organic-walled dinoflagellate cyst stratigraphy in an expanded Oligocene-Miocene boundary section in the eastern North Sea Basin (Frida-1 Well, Denmark) and correlation from basinal to marginal areas
}

\author{
KAREN DYBKJÆR \& ERIK SKOVBJERG RASMUSSEN \\ Geological Survey of Denmark and Greenland (GEUS), Øster Voldgade 10, DK-1350 Copenhagen K, Denmark \\ (e-mail: kd@geus.dk; esr@geus.dk)
}

\begin{abstract}
The organic-walled dinoflagellate cyst (dinocyst) assemblages in an unusually thick $(>800 \mathrm{~m})$ Oligocene-Miocene boundary succession from the eastern North Sea Basin (the Frida-1 Well) were studied. Six successive dinocyst assemblages are described: the Wetzeliella gochtii Assemblage (early Chattian), the Distatodinium biffii Assemblage (Chattian), the Deflandrea phosphoritica Assemblage (latest Chattian), the Homotryblium spp. Assemblage (early Aquitanian), the Caligodinium amiculum Assemblage (Aquitanian) and the Cordosphaeridium cantharellus Assemblage (latest Aquitanian to early Burdigalian). The dinocyst assemblages are compared with informal dinocyst zonations proposed for the southern North Sea Basin (Germany, Belgium and the Netherlands).

A correlation of the expanded basinal succession in Frida-1 with the marginal marine succession found onshore Jylland, based on the dinocyst stratigraphy combined with well logs and seismic data, is proposed. This correlation confirms earlier proposed datings of the onshore deposits and the presence of several hiati. Furthermore, the correlation made it possible to subdivide the succession in Frida-1 into the sequences $\mathrm{A}-\mathrm{C}$, as defined onshore. The Mi-1 glaciation event and thus the Oligocene-Miocene boundary are proposed to correlate to the boundary between sequences A and B. J. Micropalaeontol. 26(1): 1-17, April 2007.
\end{abstract}

KEYWORDS: North Sea, Oligocene-Miocene, organic-walled dinoflagellate cysts, sequence stratigraphy, Mi-1 glaciation event

\section{INTRODUCTION}

The Global Stratotype Section and Point (GSSP) for the base of the Neogene System, and thus for the Oligocene-Miocene boundary, is defined in the Lemme-Carrosio section in northern Italy (Steininger et al., 1997). The final ratification of the GSSP in 1996 initiated a series of studies (e.g. Flower et al., 1997; Zachos et al., 1997, 2001a; Paul et al., 2000; Shackleton et al., 2000) aimed at locating the boundary in other parts of the world, and testing the existence of a global climatic change near the Oligocene-Miocene boundary, the Mi-1 glaciation event, as proposed by Miller et al. (1987, 1991).

The understanding of the Upper Oligocene-Lower Miocene succession onshore Denmark, in Jylland (Fig. 1) has improved considerably during the last couple of years due to a series of new boreholes, new seismic data and studies of outcrops. The new interest in these deposits is related to the presence of large and relatively shallow sandbodies, comprising aquifers for groundwater. The succession represents the marginal parts of the eastern North Sea Basin and the sediments were deposited in alternating back-barrier, deltaic and inner- and outer-shelf environments (Larsen \& Dinesen, 1959; Friis et al., 1998; Rasmussen \& Dybkjær, 2005). A sequence stratigraphic model (Dybkjær, 2004a; Rasmussen, 2004a; Rasmussen \& Dybkjær, 2005) has been built up by correlating a number of boreholes and outcrops, using a combination of organic-walled dinoflagellate cyst (dinocyst) stratigraphy, log correlations and a few seismic lines. The model indicates the presence of several minor and major hiati and the dating of the stratigraphically incomplete succession is somewhat problematic in places.

The amount of data from the Oligocene-Miocene succession in the Danish North Sea sector has also improved during the last decade, as a number of new wells have been drilled and large amounts of new seismic data have been generated (e.g. Michelsen et al., 1998; Rasmussen, 2004b). However, as the targets for the seismic study and the wells have been deeper lying, possible hydrocarbon-bearing successions, the OligoceneMiocene succession has been ignored and most data from this interval have never been published. The geology of this part of the North Sea succession is, therefore, presently not very well known. Palynological data of varying quality can be found in unpublished reports, while published palynological information from the Oligocene-Miocene succession in the North Sea area is very limited (see below).

The Danish North Sea well Frida-1 (Fig. 1) comprises a remarkably thick and presumably complete Upper OligoceneLower Miocene marine succession. The purpose of the present study is: (1) to document the dinocyst assemblages in an expanded Upper Oligocene-Lower Miocene succession in the eastern North Sea Basin, exemplified by the Frida-1 Well; (2) to testify the age of the sequences defined onshore and the proposed hiati by correlating the onshore succession with the stratigraphically more complete succession in Frida-1; (3) to subdivide the succession in Frida-1 using the sequence stratigraphic model defined onshore; and (4) to try to locate the Mi-1 glaciation event and the Oligocene-Miocene boundary within the succession in the Danish North Sea sector.

\section{REGIONAL GEOLOGICAL SETTING}

The North Sea Basin was formed as a failed rift basin in Jurassic times (Ziegler, 1982; Vejbæk, 1992). The sea was at its maximum extent during the Late Cretaceous when chalk and limestone 


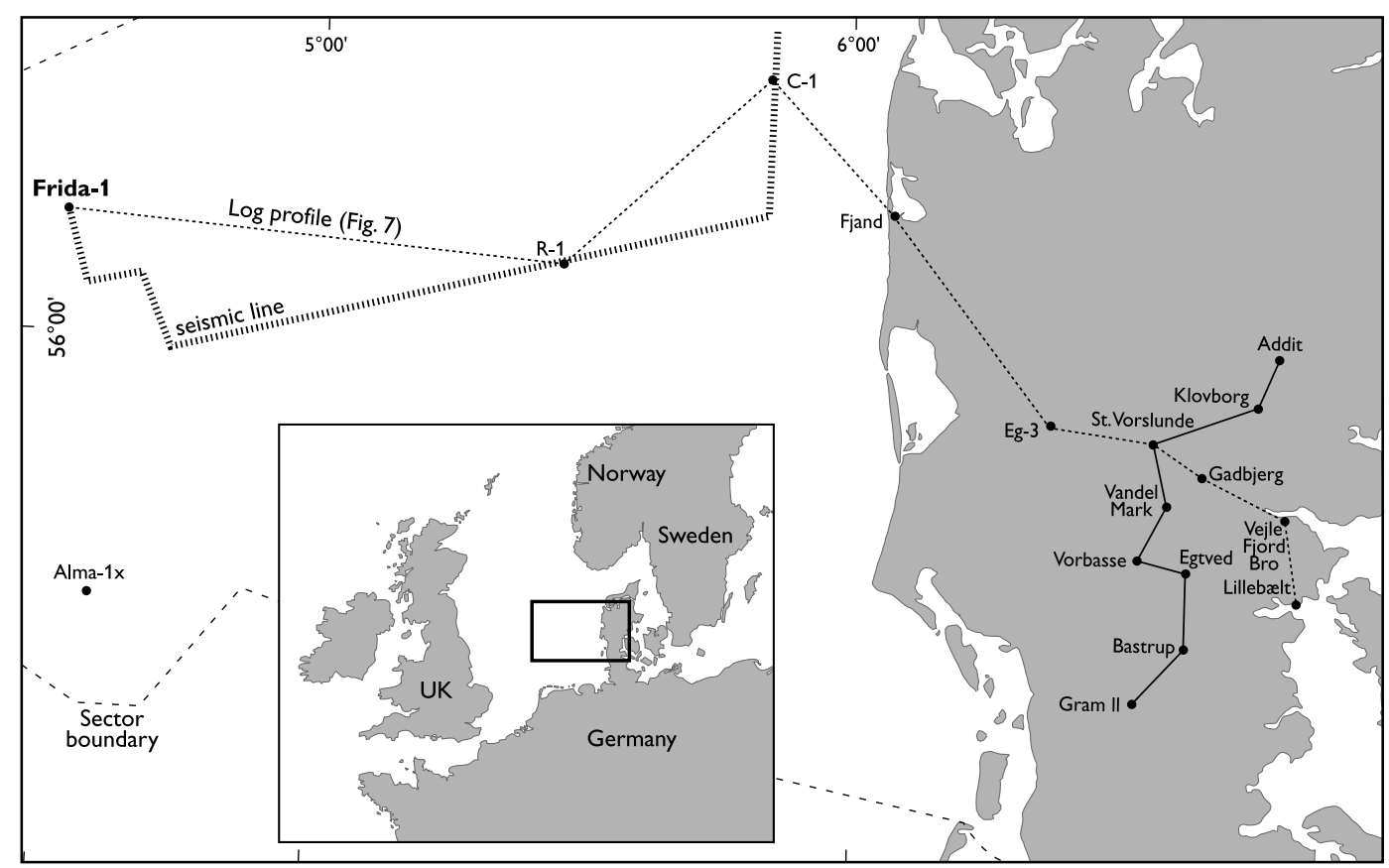

Fig. 1. Location of the Frida-1 Well and of the boreholes onshore Jylland studied by Dybkjær (2004a, b). The locations of the seismic section shown in Figure 6 and of the log-panel shown in Figure 7, respectively, are also indicated.

were deposited. Large palaeogeographical changes in the Paleocene, reflecting the Alpine orogenesis and the initial opening of the North Atlantic, resulted in distinct changes in the depositional pattern in the southern North Sea area. The sedimentation changed from the chalk-dominated biogenic deposits of the Late Cretaceous and Early Paleocene to siliciclastic deposits, at times interlayered with ash-layers during the Late Paleocene (Heilmann-Clausen, 1995a).

During the Paleocene, Eocene and most of the Oligocene, initial tectonic inversion of the western parts of the Fennoscandian Shield resulted in a marked southward progradation of the coastline. Coarse-grained, marginal marine sediments were deposited south of Norway (Jordt et al., 1995) while the deposits in the Danish area consisted of basinal marine clays.

In the latest Oligocene the Palaeogene progradation had reached the present-day Danish North Sea area and the palaeoshoreline was located in the Danish area, orientated WNWESE. In the most marginal parts of the basin (e.g. onshore Jylland) an inner-shelf environment existed, as described by Larsen \& Dinesen (1959), Friis et al. (1998), Rasmussen (2004a) and Rasmussen \& Dybkjær (2005). In the deeper parts of the basin, outer-shelf and slope environments prevailed (Michelsen et al., 1998; Rasmussen, 2004b). The height of the clinoforms seen in seismic sections (this study) indicate water depths exceeding $500 \mathrm{~m}$ and a succession of gravity deposits, interfingering with deep marine clay, was deposited.

In the earliest Miocene (the early Aquitanian) the environment changed to contourite deposition along the shelf slope (Hansen et al., 2004). In the marginal marine areas, spit-systems, deltas and lagoons prevailed (Larsen \& Dinesen, 1959; Friis et al., 1998; Rasmussen, 2004a; Rasmussen \& Dybkjær, 2005). Probably as a result of a major sea-level fall, a major hiatus represents the upper Aquitanian-lowermost Burdigalian in large parts of Jylland, while a major delta was deposited in the southeastern part of Jylland (Rasmussen, 1996, 2004a; Dybkjær \& Rasmussen, 2000; Dybkjær, 2004a). In the basinal areas contouritic clays were deposited continuously. The lower to mid-Burdigalian succession onshore is represented by lagoonal and inner-shelf deposits, while marine-shelf sediments were deposited in the basinal areas.

A series of sea-level changes resulted in several hiati developing in the marginal parts of the basin and influenced the location of the coastline and the depositional environment (Dybkjær \& Rasmussen, 2000; Rasmussen, 2004a, b; Dybkjær, 2004a; Rasmussen \& Dybkjær, 2005). Tectonism also influenced the depositional setting. The Salian tectonic event in the midOligocene initiated salt movement and reactivation of older fault segments, e.g. the Brande Trough. The Betic event, in the late Early Miocene, also affected the eastern North Sea Basin, as indicated by reactivation of salt structures and increased influx of siliciclastic sediments (Rasmussen, 2004b). The climate in the Late Oligocene-Early Miocene was humid, varying between cold temperate to subtropical (Sorgenfrei, 1958; Lotsch, 1968; Radwanski et al., 1975; Buchardt, 1978).

\section{ONSHORE STRATIGRAPHY}

A sequence stratigraphic model for the uppermost OligoceneMiocene succession in the central and southern parts of Jylland was proposed by Rasmussen (2004a). The uppermost Oligocene-Lower Miocene part of the succession was subdivided into three sequences, A-C (Fig. 2). Dybkjær (2004a, b) presented the variations in the dinocyst assemblages in a series of boreholes onshore Jylland (Fig. 1) and the ages of the sequences were discussed. This is summarized in the following sections. 


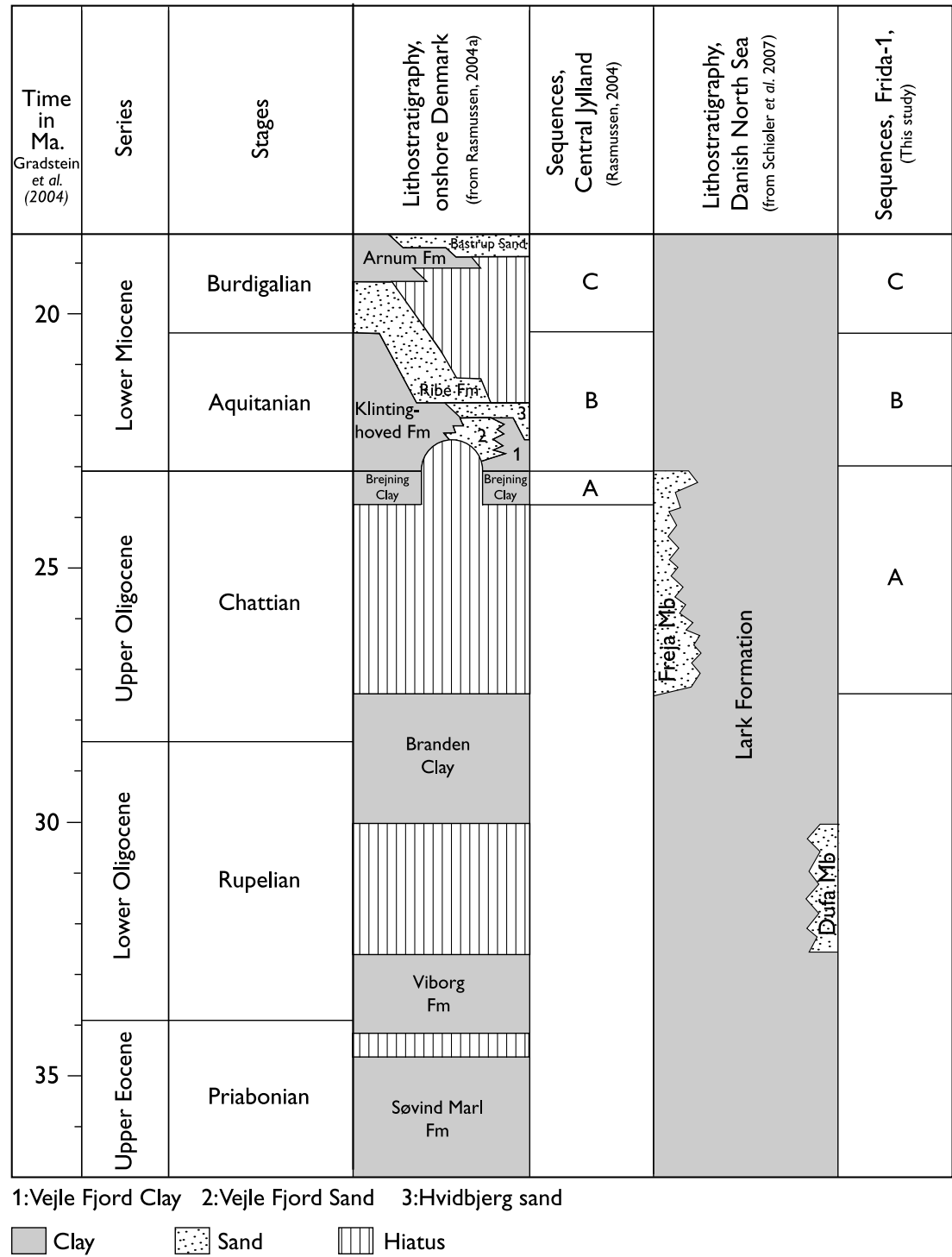

Fig. 2. Chronostratigraphy, lithostratigraphy and sequence stratigraphy onshore Jylland (Rasmussen, 2004a), lithostratigraphy in the Danish North Sea area (Schiøler et al., in press) and sequence stratigraphy in Frida-1. Time-scale from Gradstein et al. (2004).

\section{Sequence A (latest Chattian)}

In the area studied by Rasmussen (2004a) and Dybkjær (2004a) a large hiatus occurs at the basal boundary of Sequence A. Marls of Middle to Late Eocene age (the Søvind Marl) are overlain by organic-rich clayey inner-shelf deposits, referred to the Brejning Clay Member - the lowest member of the Vejle Fjord Formation (Larsen \& Dinesen, 1959) (Fig. 2).

The dinocyst assemblage of Sequence A is characterized by a common occurrence of Distatodinium paradoxum, Hystrichokolpoma rigaudiae and Operculodinium centrocarpum in the transgressive systems tract (TST), while the relative abundances of Chiropteridium galea, Deflandrea phosphoritica and Homotryblium plectilum increase in the highstand systems tract (HST), towards the upper sequence boundary (Dybkjær, 2004a, b).

There is general agreement for a Late Oligocene (Chattian) age assignment for the Brejning Clay (and thus for Sequence A), but a more exact limitation within the Chattian is not clear. Molluscs in the lower part indicate a Late Oligocene age,
Chattian B (Schnetler \& Beyer, 1987, 1990). Foraminifera from the same part also indicate a Late Oligocene age (King, 1983; Ulleberg, 1987), for example in the Danish Harre-1 borehole, King (1994) dated it as latest Chattian. The absence of the dinocyst species Distatodinium biffii made Dybkjær (2004a) suggest that Sequence A should be referred to the uppermost Chattian. According to Powell \& Brinkhuis (2004a) the last occurrence of D. biffii is at $24.4 \mathrm{Ma}$ (Fig. 3).

\section{Sequence B (early Aquitanian)}

Sequence B comprises a succession deposited in a marginal, partly restricted marine environment. The organic-rich clay is referred to the Vejle Fjord Clay (Larsen \& Dinesen, 1959); in addition the sequence includes several sand units of different origin, e.g. the Vejle Fjord Sand (storm sand) (Larsen \& Dinesen, 1959), the informal Hvidbjerg sand (spit system sand) and the informal Billund sand (deltaic) (see Rasmussen, 2004a). 
K. Dybkjær \& E. S. Rasmussen

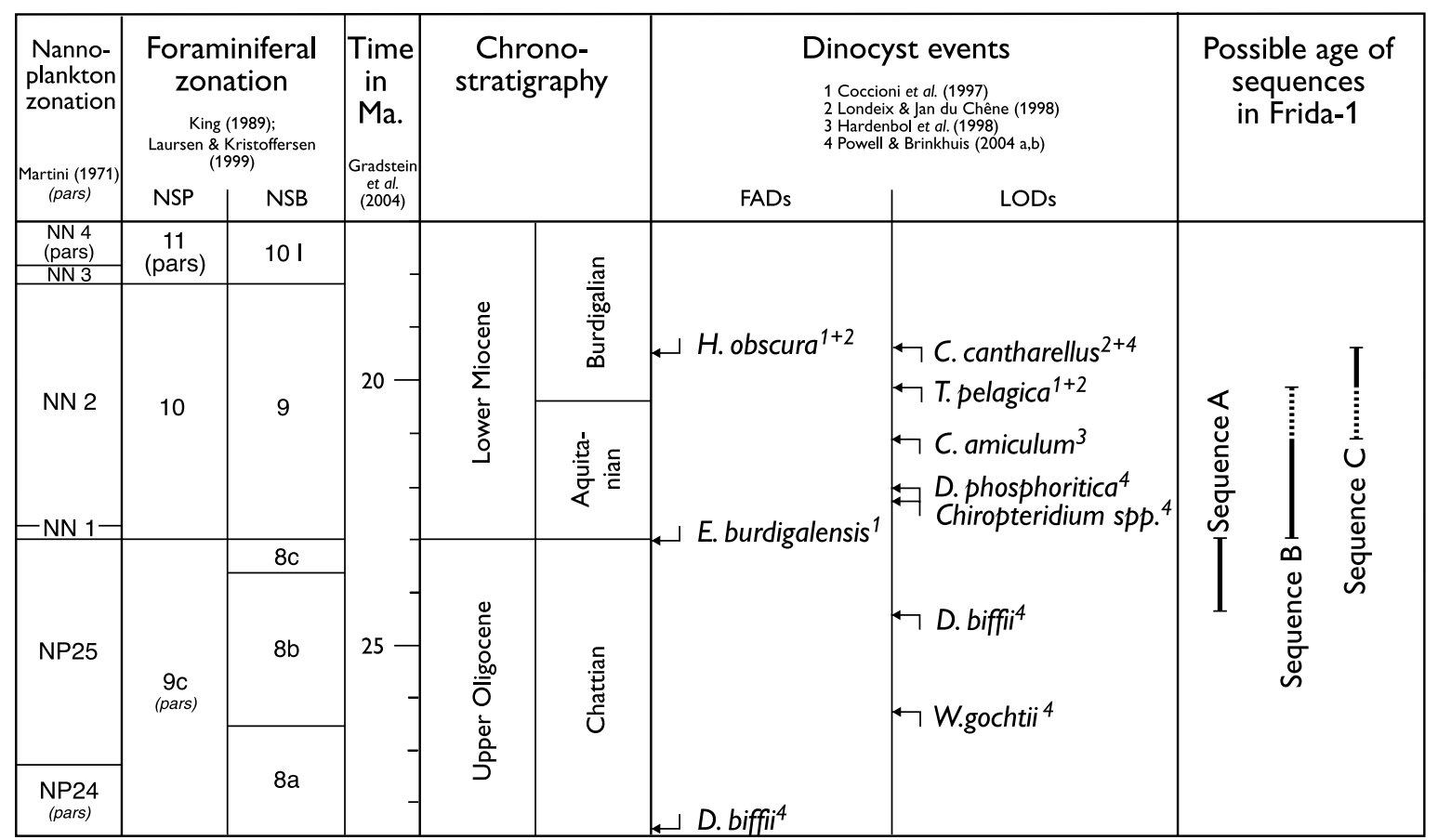

Fig. 3. Stratigraphically important dinocyst events correlated with chronostratigraphy according to the literature (Coccioni et al., 1997; Hardenbol et al., 1998; Londeix \& Jan du Chêne, 1998; Powell \& Brinkhuis, 2004a, b). The dinocyst events are correlated to nannoplankton zonation (Martini, 1971), foraminiferal zonation (King, 1989; Laursen \& Kristoffersen, 1999), absolute age and chronostratigraphy. The possible age of the sequences in Frida-1 is shown. Time-scale from Gradstein et al. (2004).

Palynologically, the boundary between sequences A and B is characterized by a distinct decrease in relative abundance of Deflandrea phosphoritica and Chiropteridium galea. In Sequence B these species occur only sporadically. Otherwise, the sparse dinocyst assemblage of Sequence B is characterized by common to abundant occurrence of Homotryblium spp. and the sporadic occurrence of Caligodinium amiculum and Glaphyrocysta cf. vicina (Dybkjær, 2004a, b).

Sequence B is dated as latest Chattian and/or early Aquitanian based on the sporadic occurrences of Chiropteridium galea, Deflandrea phosphoritica and Caligodinium amiculum throughout the sequence (Hardenbol et al., 1998; Dybkjær, 2004a; Powell \& Brinkhuis, 2004b) (Fig. 3). The index taxon Ectosphaeropsis burdigalensis appears in the upper part of the sequence (Dybkjær, 2004a). This species appears immediately below the Oligocene/Miocene boundary in the Italian type section (Coccioni et al., 1997) and in the stratotype area for the Rupelian-Chattian it was found to appear in the upper part of the Chattian (Van Simaeys et al., 2004). Its appearance in Sequence B onshore Jylland may have been delayed due to the restricted marine depositional environment (Dybkjær, 2004a). According to Brinkhuis (pers. comm. 2006), the indication of this event in the earliest Aquitanian in Williams et al. (2004) is an error.

Correlation with eustatic sea-level curves (Prentice \& Matthews, 1988; Zachos et al., 2001b) indicates that the Oligocene-Miocene boundary is located at the boundary between sequences $\mathrm{A}$ and $\mathrm{B}$, and that Sequence B is, thus, of early Aquitanian age (Dybkjær, 2004a; Rasmussen, 2004b).

\section{Sequence C (early Burdigalian)}

In large parts of Jylland there is a hiatus between sequences $\mathrm{B}$ and $\mathrm{C}$, spanning the late Aquitanian-earliest Burdigalian (Dybkjær \& Rasmussen, 2000; Dybkjær, 2004 a, b; Rasmussen, 2004a; Rasmussen \& Dybkjær, 2005). Sequence C clearly consists of more open-marine deposits than Sequence B (Dybkjær, 2004a; Rasmussen \& Dybkjær, 2005). The marine clays of Sequence $\mathrm{C}$ are referred to the Arnum Formation (Sorgenfrei, 1958), while the more coarse-grained, fluvio-deltaic deposits are referred to the informal Bastrup sand (Rasmussen, 2004a).

The dinocyst assemblage shows a distinct change across the boundary between the sequences $\mathrm{B}$ and $\mathrm{C}$, from a lowdiversity Homotryblium-dominated assemblage to a higherdiversity assemblage dominated by Impletosphaeridium insolitum, Operculodinium centrocarpum, Spiniferites spp. and Cleistosphaeridium placacanthum. Homotryblium spp. occurs only sporadically.

The last occurrence of Thalassiphora pelagica and the first occurrence of Hystrichosphaeropsis obscura in the lower part of Sequence $\mathrm{C}$ indicate an early Burdigalian age (Coccioni et al., 1997; Hardenbol et al., 1998; Londeix \& Jan du Chêne, 1998; Powell \& Brinkhuis, 2004b) (Fig. 3). The last occurrence of Cordosphaeridium cantharellus in the sequence above indicates an age not younger than early Burdigalian (Londeix \& Jan du Chêne 1998; Powell \& Brinkhuis, 2004b). An early Burdigalian age for the lower part of the Arnum Formation is supported by earlier studies of dinocysts (Dybkjær \& Rasmussen, 2000; Dybkjær, 2004a) and of foraminifera (Laursen \& Kristoffersen, 1999). 


\section{PREVIOUS PALYNOSTRATIGRAPHIC STUDIES OF THE UPPER OLIGOCENE-LOWER MIOCENE IN THE NORTH SEA AREA}

Palynological data from the Upper Oligocene-Lower Miocene succession in the Danish area comprise the studies of the two North Sea wells Mona-1 (Michelsen et al., 1998) and Alma-1 (Schiøler, 2005), and the studies of onshore boreholes and outcrops by Dybkjær \& Rasmussen (2000), Dybkjær (2004a, b), Rasmussen \& Dybkjær (2005) and Rasmussen et al. (2006).

Several studies have also been made from Germany, e.g. Maier (1959), Gerlach (1961), Benedek (1972), Benedek \& Müller (1974), Heilmann-Clausen \& Costa (1989), Köthe (1990, 1996, 2000, 2003a, b, 2004, 2005), Köthe et al. (2002), Lund et al. (1993), Lund \& Heilmann-Clausen (2001) and Strauss et al. (2001).

More recently Van Simaeys et al. (2004) presented the results of a study on the Rupelian and Chattian in their type regions in Belgium and Germany and Van Simaeys et al. (2005) presented a zonation for the Oligocene in the southern North Sea Basin. Before that, data from Belgium were presented by Louwye \& Laga (1998) and Louwye et al. (1999, 2000).

Herngreen $(1983,1987)$ has published papers on Miocene dinocyst stratigraphy from the Netherlands and recently Munsterman \& Brinkhuis (2004) published an informal zonation for the Miocene succession in the southern North Sea Basin, based on data from the Netherlands. Powell (1992) presented an informal zonation for the British offshore area.

Very little information about Upper Oligocene-Lower Miocene palynology from the central and northern North Sea area is available at present. From the northern North Sea there is an abstract by Costa (1980) and from the central North Sea area there is the overall zonation by Gradstein et al. (1992).

\section{MATERIAL AND METHODS}

The Frida-1 Well is located in the basinal part of the Danish North Sea area (Fig. 1). The studied succession comprises the interval from 980-1740 m. Borehole casing placed around $970 \mathrm{~m}$ reduced caving of younger sediments below that level (the samples above that level were contaminated strongly by caved material). The cuttings samples used in the present study are thus of high quality and allow, with caution, the use of first appearances (last downhole occurrences) and percentage variations of specific species for stratigraphic purposes. Lithostratigraphically, the studied succession is referred to the Lark Formation (Knox \& Holloway, 1992); the sandy interval from $1486-1622 \mathrm{~m}$ is referred to the Freja Member (Schiøler et al., in press) (Fig. 2).

A total of 37 ditch cuttings samples and four conventional core samples were studied (Figs 4, 5). The ditch cuttings samples represent intervals of $5 \mathrm{~m}$ or $10 \mathrm{~m}$ (980-1390 m: $10 \mathrm{~m}$ interval; 1390-1740 m: $5 \mathrm{~m}$ interval). The depths for the ditch cuttings samples shown in Figures 4 and 5 are the base depths of the interval represented by each sample. The depths indicated as base or top of a dinocyst assemblage correspond to the depth in between the base depths of the ditch cuttings sample from which the dinocyst event defining the boundary was encountered and the sample above (Figs 4, 5).

The sample material was processed using standard palynological preparatory methods including treatment with $\mathrm{HF}$ and
$\mathrm{HCl}$ to dissolve silicates and heavy liquid separation to remove the undissolved mineral matter. The residue was sieved using an $11 \mu \mathrm{m}$ mesh, and mild oxidation with dilute nitric acid was carried out. One slide for kerogen studies was produced, by mounting the organic residue in glycerine jelly. Following sieving through a $20 \mu \mathrm{m}$ mesh to concentrate the dinocysts, two additional slides were produced. The material was studied using a normal light microscope.

A minimum of 200 dinocysts was counted in each sample. Fresh-water algae and acritarchs recorded during this process were also counted. Additionally, two full slides were inspected in order to register rare species. The slides are stored at the Geological Survey of Denmark and Greenland (GEUS). A number of stratigraphically important species are shown in Plate 1. The LVR numbers refer to file numbers in the image database of GEUS from where further information about the illustrated species can be extracted.

\section{RESULTS}

The results from the palynological study in Frida- 1 are presented in Figure 4. Based on the variations in the occurrence of dinocysts, six dinocyst assemblages are defined and described in the following, starting with the oldest assemblage.

\section{The Wetzeliella gochtii Assemblage}

Occurrence in Frida-1: 1740-1685 m (Fig. 5).

Base: Not defined here.

Top: The last occurrence of the Wetzeliella gochtii/W. symmetrica group.

General characteristics: This assemblage is characterized by the co-existence of the Wetzeliella gochtiilW. symmetrica group and Distatodinium biffii. Spiniferites spp. dominate the assemblage.

Important events within the zone: Last occurrences of Areoligera semicirculata, Rhombodinium draco and Svalbardella cooksoniae at $1720 \mathrm{~m}$ (Fig. 5).

Age: Early Chattian. The occurrence of Distatodinium biffii at $1740 \mathrm{~m}$ indicates an age not older than the Chattian (Powell \& Brinkhuis, 2004a) (Fig. 3). Sporadic occurrences of specimens very much like $D$. biffii in an Eocene section in Denmark (Heilmann-Clausen \& Van Simaeys, 2005) indicate, however, that the first occurrence of this species may be older than hitherto thought. The last occurrence of the Wetzeliella gochtii/W. symmetrica group at $1700 \mathrm{~m}$ indicates an age not younger than the early Chattian (Powell \& Brinkhuis, 2004a) (Fig. 3).

\section{The Distatodinium biffii Assemblage}

Occurrence in Frida-1: 1685-1620 m (Fig. 5).

Base: The last occurrence of the Wetzeliella gochtii/W. symmetrica group.

Top: The last occurrence of Distatodinium biffii.

General characteristics: Distatodinium biffii occurs consistently. The assemblage is dominated by Spiniferites spp. and Cleistosphaeridium placacanthum.

Important events within the zone: None.

Age: Chattian. The last occurrence of the Wetzeliella gochtiil $W$. symmetrica group at $1700 \mathrm{~m}$ indicates an early Chattian age for the assemblage below, while the last occurrence of 
Dinoflagellate Cysts

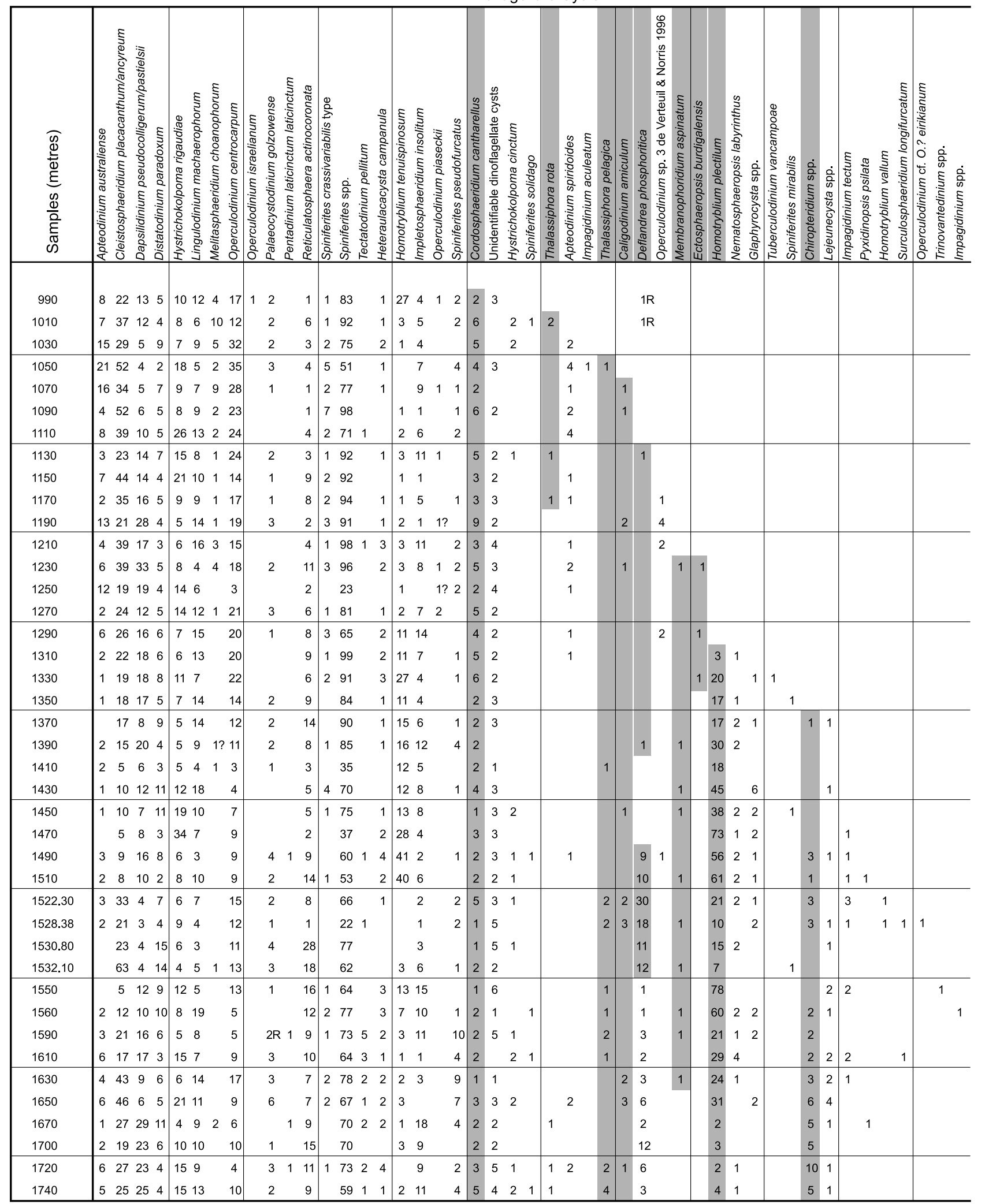

Fig. 4. Range chart, showing all the registered dinocysts, acritarchs and freshwater algae. The light grey shaded areas show the occurrence of stratigraphically important events used for defining the dinocyst assemblages in the present study. R, reworked; ?, questionable identification. 


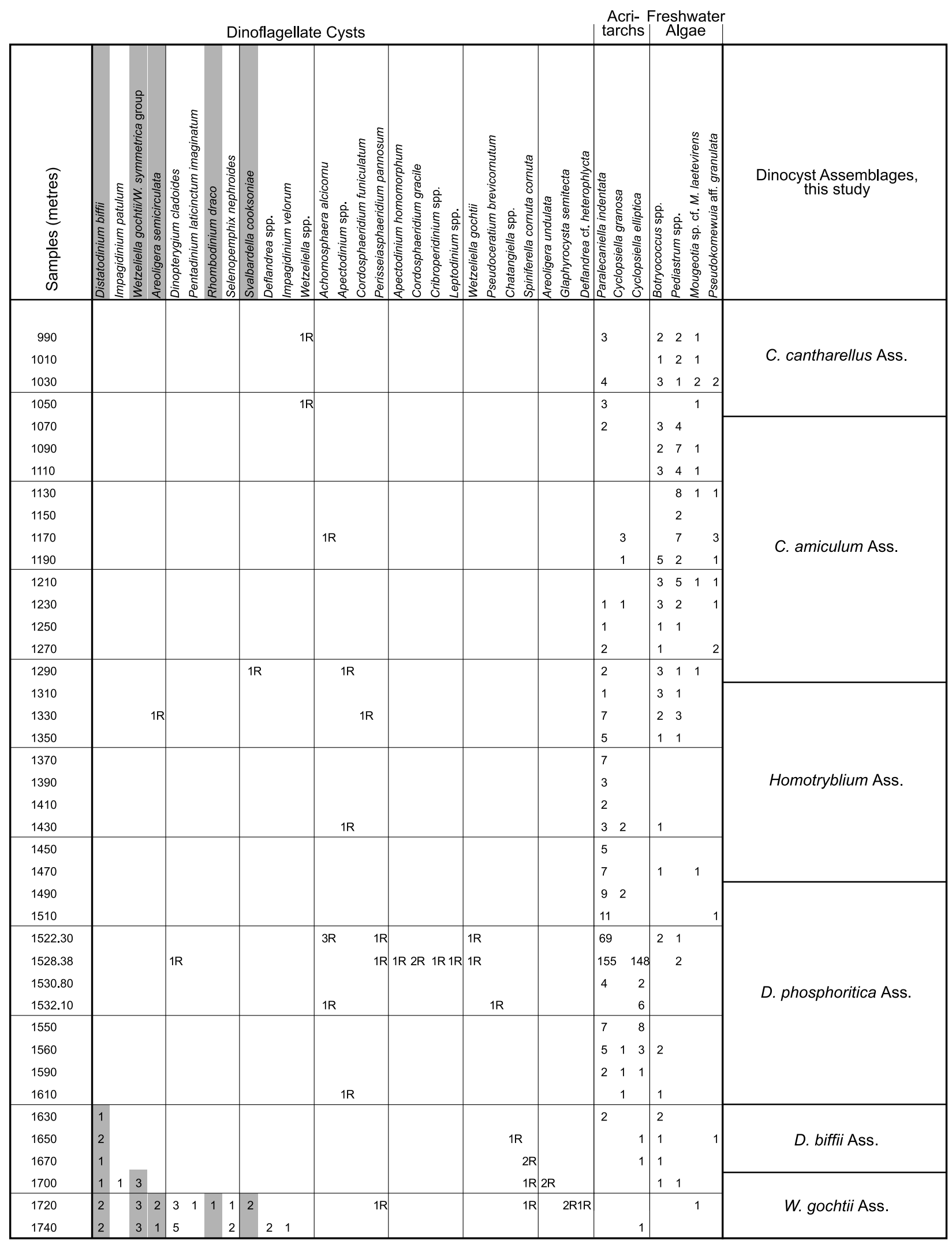

Fig. 4. Continued 
K. Dybkjær \& E. S. Rasmussen

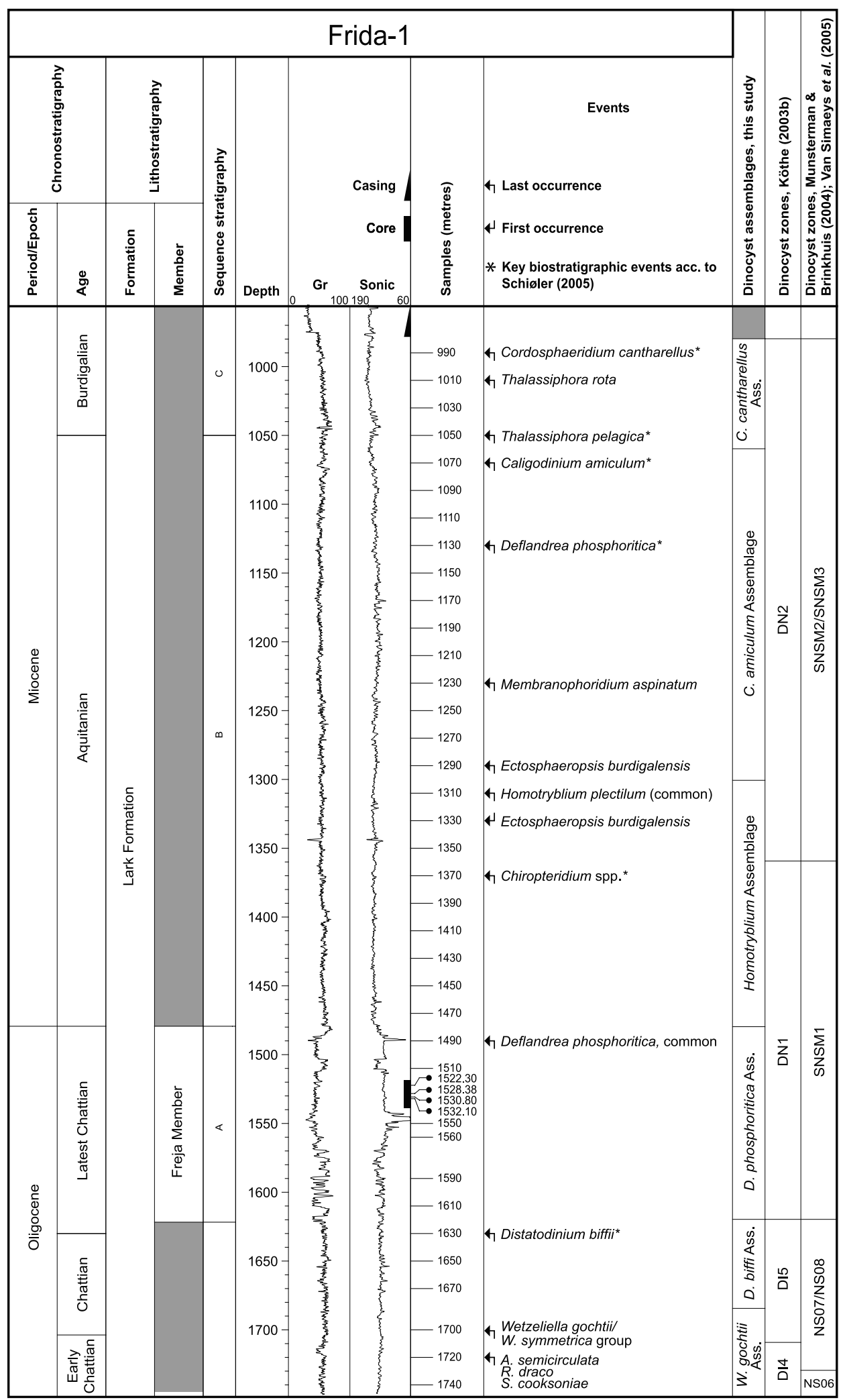

Fig. 5. Chrono-, litho- and sequence stratigraphy of the studied succession in Frida-1. The location of samples, the cored interval and the casing is shown. The location of the stratigraphically important events (Schiøler, 2005) are also indicated and the dinocyst assemblages of the present study are compared with previously defined zonations (Köthe, 2003b; Munsterman \& Brinkhuis, 2004; Van Simaeys et al., 2005) for the southern North Sea area. 
North Sea Oligocene-Miocene dinoflagellate cysts
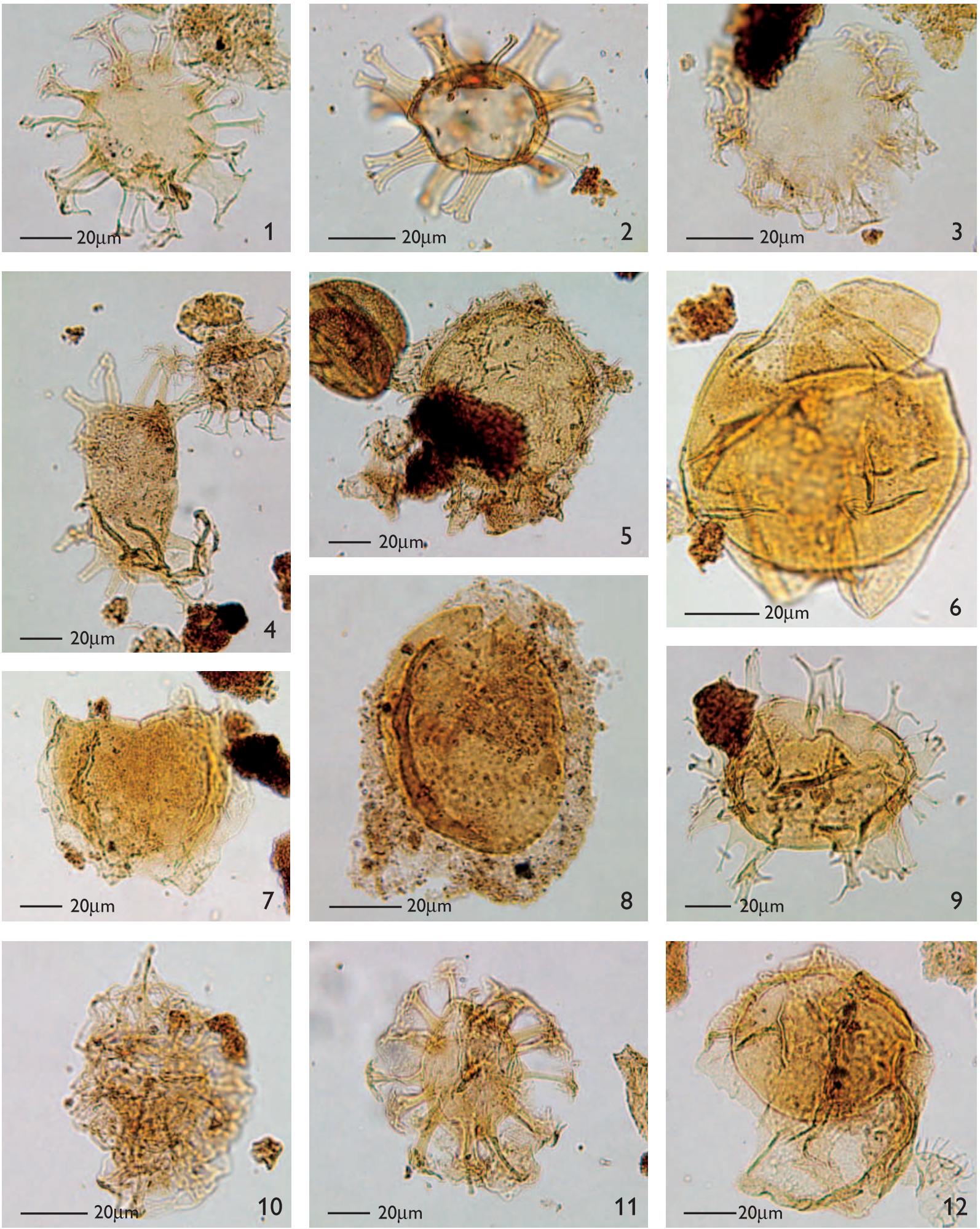

Plate 1.

Explanation of Plate 1. Stratigraphically important dinocyst species from the Frida 1 Well. Magnification is shown by the $20 \mu \mathrm{m}$ bar on each figure. fig. 1. Areoligera semicirculata (Morgenroth, 1966) Stover \& Evitt, 1978. LVR 27680. fig. 2. Homotryblium plectilum Drugg \& Loeblich, 1967. LVR 27672. fig. 3. Glaphyrocysta spp. LVR 27659. fig. 4. Distatodinium biffii Brinkhuis et al., 1992. LVR 27653. fig. 5. Wetzeliella gochtii Costa \& Downie, 1976. LVR 22779. fig. 6. Deflandrea phosphoritica Eisenack 1938. LVR 27622. fig. 7. Membranophoridium aspinatum Gerlach, 1961. LVR 27629. fig. 8. Caligodinium amiculum Drugg 1970. LVR 27684. fig. 9. Chiropteridium galea (Maier, 1959) Sarjeant, 1983. LVR 27647. fig. 10. Ectosphaeropsis burdigalensis Londeix \& Jan du Chêne, 1988. LVR 27637. fig. 11. Cordosphaeridium cantharellus (Brosius, 1963) Sarjeant, 1981. LVR 27600. fig. 12. Thalassiphora pelagica (Eisenack, 1954) Eisenack \& Gocht, 1960. LVR 27608. 
Distatodinium biffii at $1630 \mathrm{~m}$ indicates a latest Chattian age for this assemblage (Powell \& Brinkhuis, 2004a) (Fig. 3). In the Italian type section, the last occurrence of Distatodinium biffii occurs closely below ( $9 \mathrm{~m}$ below) the Oligocene-Miocene boundary (Zevenboom, 1996). In studies by Munsterman \& Brinkhuis (2004) on Dutch material and by Van Simaeys et al. (2005) on material from Belgium, northern Germany and the Netherlands, the last occurrence of $D$. biffii was also recorded in the upper part of the Chattian.

\section{The Deflandrea phosphoritica Assemblage}

Occurrence in Frida-1: 1620-1480 m (Fig. 5).

Base: The last occurrence of Distatodinium biffii.

Top: The last occurrence of common Deflandrea phosphoritica. General characteristics: Dominated by Homotryblium plectilum and Spiniferites spp. Deflandrea phosphoritica, Chiropteridium spp. and Membranophoridium aspinatum occur consistently. In the upper part of the interval the relative abundances of $D$. phosphoritica and Homotryblium spp. increase. The acritarch species Cyclopsiella elliptica and Paralecaniella indentata occur abundantly at $1530.80 \mathrm{~m}$ (core) and $1528.38 \mathrm{~m}$ (core).

Important events within the zone: None.

Age: Latest Chattian. The last occurrence of D. biffi $i$ at the base of the zone indicates an age not older than the latest Chattian (Coccioni et al., 1997; Van Simaeys et al., 2004; Powell \& Brinkhuis, 2004a) (Fig. 3). The last occurrence of Chiropteridium spp. at $1370 \mathrm{~m}$, in the assemblage above, indicates an earliest Aquitanian age (Powell \& Brinkhuis, 2004a), while the first occurrence of Ectosphaeropsis burdigalensis at $1330 \mathrm{~m}$ indicates a very latest Chattian age (Coccioni et al., 1997) (Fig. 3).

\section{The Homotryblium Assemblage}

Occurrence in Frida-1: 1480-1300 m (Fig. 5).

Base: The last occurrence of common Deflandrea phosphoritica. Top: The last occurrence of common Homotryblium spp.

General characteristics: Dominated by Homotryblium plectilum, H. tenuispinosum and Spiniferites spp. Sporadic occurrences of Chiropteridium spp., Membranophoridium aspinatum and Deflandrea phosphoritica. Ectosphaeropsis burdigalensis occurs in a narrow interval in the uppermost part. The relative abundance of Homotryblium plectilum decreases gradually upwards.

Important events within the zone: Last occurrence of Chiropteridium spp. at $1370 \mathrm{~m}$, Homotryblium plectilum at $1310 \mathrm{~m}$ and Glaphyrocysta spp. at $1330 \mathrm{~m}$. First occurrence of Ectosphaeropsis burdigalensis at $1330 \mathrm{~m}$ and last occurrence at $1290 \mathrm{~m}$.

Age: Early Aquitanian. The last occurrence of Distatodinium biffii in the succession below indicates an age not older than the latest Chattian (Coccioni et al., 1997; Powell \& Brinkhuis, 2004a) (Fig. 3). The first occurrence of Ectosphaeropsis burdigalensis at $1330 \mathrm{~m}$ indicates a latest Chattian age (Coccioni et al., 1997) (Fig. 3). The occurrence of Chiropteridium spp. up to $1370 \mathrm{~m}$ indicates an age not younger than the early Aquitanian (Powell \& Brinkhuis, 2004a).

\section{The Caligodinium amiculum Assemblage}

Occurrence in Frida-1: 1300-1060 m (Fig. 5).

Base: The last occurrence of common Homotryblium spp.
Top: The last occurrence of Caligodinium amiculum.

General characteristics: Dominated by Spiniferites spp. and Cleistosphaeridium placacanthum. Hystrichokolpoma rigaudiae and Operculodinium centrocarpum are common to dominant. Sporadic occurrences of Caligodinium amiculum, Deflandrea phosphoritica, Homotryblium spp., Membranophoridium aspinatum, Operculodinium piaseckii and Thalassiphora pelagica. Important events within the zone: The last occurrence of Membranophoridium aspinatum at $1230 \mathrm{~m}$ and Deflandrea phosphoritica at $1130 \mathrm{~m}$. The first occurrence of Operculodinium piaseckii at $1270 \mathrm{~m}$ may also be important. The freshwater dinocyst species Pseudokomewuia aff. granulata (Batten et al., 1999) appears at the base of this interval.

Age: Aquitanian. The occurrence of Ectosphaeropsis burdigalensis in the succession below strongly indicates an age not older than the Aquitanian (Coccioni et al., 1997) (Fig. 3). The last occurrence of Deflandrea phosphoritica at $1130 \mathrm{~m}$ and Caligodinium amiculum at $1070 \mathrm{~m}$ indicates an age not younger than the Aquitanian (Hardenbol et al., 1998; Powell \& Brinkhuis, 2004a).

\section{The Cordosphaeridium cantharellus Assemblage}

Occurrence in Frida-1: 1060-?980 m (Fig. 5).

Base: The last occurrence of Caligodinium amiculum.

Top: The last occurrence of Cordosphaeridium cantharellus. This species was not recorded in samples above $990 \mathrm{~m}$, but, as the samples immediately above $980 \mathrm{~m}$ are full of caved dinocysts (and the in situ assemblage thus diluted), the 'true' last occurrence of $C$. cantharellus may be higher up-section.

General characteristics: Dominated by Operculodinium centrocarpum, Spiniferites spp. and Cleistosphaeridium placacanthum. Consistent occurrence of Operculodinium piaseckii. Homotryblium tenuispinosum is dominant at $990 \mathrm{~m}$.

Important events within the zone: The last occurrence of Thalassiphora pelagica at $1050 \mathrm{~m}$ and Thalassiphora rota at $1010 \mathrm{~m}$ (Fig. 5).

Age: Early Miocene (latest Aquitanian to early Burdigalian). The last occurrence of Caligodinium amiculum at $1070 \mathrm{~m}$ indicates an age not older than the latest Aquitanian (Hardenbol et al., 1998) (Fig. 3). The last occurrence of Thalassiphora pelagica at $1050 \mathrm{~m}$ and Thalassiphora rota at $1010 \mathrm{~m}$ indicates an earliest Burdigalian age (Coccioni et al., 1997; Londeix \& Jan du Chêne, 1998; Schiøler, 2005). The occurrence of Cordosphaeridium cantharellus at $990 \mathrm{~m}$ indicates an age not younger than early Burdigalian (Londeix \& Jan du Chêne, 1998; Powell \& Brinkhuis, 2004a).

\section{CORRELATION WITH ZONATIONS AND KEY BIOSTRATIGRAPHIC EVENTS DEFINED IN NEARBY AREAS}

The dinocyst assemblages defined in the present study are correlated easily with the zonation proposed by Köthe (2003b) based on data from Germany (Fig. 5). The index markers (first and last occurrences of dinocyst species) used by Köthe for defining her zonation in the Upper Oligocene-Lower Miocene were also recorded in the present study. The zonations proposed by Van Simaeys et al. (2005) (for the Oligocene in the southern 
North Sea) and by Munsterman \& Brinkhuis (2004) (for the Miocene in the southern North Sea) are also illustrated for comparison in Figure 5.

\section{The Wetzeliella gochtii Assemblage}

In the Linde-1 borehole onshore Jylland the co-existence of Distatodinium biffii and Wetzeliella gochtii has been recorded from the interval referred to the middle part of the Branden Clay (Heilmann-Clausen, 1995b). The W. gochtii Assemblage correlates to the lower part of Dinocyst Zone D14 of Köthe (2003b) and to parts of the Dinocyst Zones NSO6-7 of Van Simaeys et al. (2005) (Fig. 5).

\section{The Distatodinium biffii Assemblage}

This interval probably corresponds to the upper part of the Branden Clay onshore Jylland (Heilmann-Clausen, 1995b). The D. biffii Assemblage correlates to Dinocyst Zone D15 of Köthe (2003b) and parts of the Dinocyst Zones NSO7 and NSO8 of Van Simaeys et al. (2005) (Fig. 5).

\section{The Deflandrea phosphoritica Assemblage}

The consistent occurrence of Chiropteridium spp. and Membranophoridium aspinatum and the increase in relative abundance of Deflandrea phosphoritica and Homotryblium plectilum in the upper part is closely comparable to Dinocyst Assemblage 1 as described in Rasmussen \& Dybkjær (2005) from outcrops referred to the Brejning Clay of latest Chattian age, and to the dinocyst assemblage described from Sequence A onshore Jylland (Dybkjær, 2004a; Rasmussen, 2004a).

The D. phosphoritica Assemblage correlates to the lower part of Dinocyst Zone DN1 of Köthe (2003b) and the lower part of Dinocyst Zone SNSM1 of Munsterman \& Brinkhuis (2004) (Fig. 5).

\section{The Homotryblium Assemblage}

The abundance of Homotryblium plectilum and H. tenuispinosum, the sporadic occurrences of Chiropteridium spp., Deflandrea phosphoritica and Caligodinium amiculum and the occurrence (in a narrow interval) of Ectosphaeropsis burdigalensis compare closely to the dinocyst assemblage in Sequence B described in Dybkjær (2004a, b) and to Assemblage 2 (Rasmussen \& Dybkjær, 2005) from outcrops referred to the Vejle Fjord Clay, Vejle Fjord Sand, Hvidbjerg sand and Billund sand.

The lower part of the Homotryblium Assemblage correlates to the upper part of Dinocyst Zone DN1 of Köthe (2003b) and the upper part of SNSM1 of Munsterman \& Brinkhuis (2004). The upper part (above the last occurrence of the index marker Chiropteridium spp.) correlates to the lower part of Dinocyst Zone DN2 (Köthe, 2003b) and to the lower part of SNSM2 of Munsterman \& Brinkhuis (2004).

\section{The Caligodinium amiculum Assemblage}

This assemblage is presently not comparable to any assemblage recorded onshore Jylland, possibly due to different facies or to a missing onshore section. A large hiatus, representing approximately 3.5 Ma, is present onshore between sequences $\mathrm{B}$ and $\mathrm{C}$ in the eastern and central parts of Jylland (Dybkjær \& Rasmussen, 2000; Dybkjær, 2004a), while a large delta (Ribe Formation) existed in the southern and western parts. The succession referred to the $C$. amiculum Assemblage in Frida-1 possibly represents the marine facies corresponding to the hiatus and the delta.

The $C$. amiculum Assemblage correlates to the middle part of the Dinocyst Zone DN2 of Köthe (2003b) and to the upper part of Dinocyst Zone SNSM2 and the lower part of SNSM3 of Munsterman \& Brinkhuis (2004) (Fig. 5). Unfortunately, Membranilarnacia? picena, the last occurrence of which is used for defining the base of zone SNSM3 in the latter zonation, was not recorded in Frida-1.

\section{The Cordosphaeridium cantharellus Assemblage}

The last occurrence of $T$. pelagica in the lower part of the interval, and the last(?) occurrence of $C$. cantharellus in the upper part, indicate a correlation with Sequence $\mathrm{C}$ onshore (the lower part of the Arnum Formation and the Bastrup sand) (Dybkjær, 2004a; Rasmussen, 2004a).

Severe caving in Frida-1 down to the casing at $970 \mathrm{~m}$ hinders a trustworthy comparison of the dinocyst assemblages above this level with assemblages from onshore sections. The $C$. cantharellus Assemblage correlates to the upper part of the Dinocyst Zone DN2 of Köthe (2003b) and the Dinocyst Zone SNSM3 of Munsterman \& Brinkhuis (2004).

\section{Comparison of the Alma-1 and Frida-1 wells}

Schiøler (2005) pointed out a number of 'key biostratigraphic events' in the Alma-1 Well located in the southern part of the Danish North Sea Sector (see location of Alma-1 in Fig. 1). In general these events correspond very well with those used for stratigraphic purposes in the present study. However, not all of the dinocyst species used by Schiøler (2005) as key events were recorded in Frida-1 (especially in the interval from the last occurrence of Thalassiphora pelagica and upwards). Key events used by Schiøler (2005) which were not recorded in Frida-1 include: Tectatodinium sp. 1 of Chateauneuf (1980), Brigantedinium? spp., Leptodinium italicum and Hystrichokolpoma 'reductum' of Zevenboom \& Santarelli in Zevenboom (1995).

The interval from the last occurrence of Distatodinium biffii to the last occurrence of Thalassiphora pelagica is expanded in Frida-1 when compared to Alma-1 and, within that interval, some important events and abundance variations were found only in Frida-1. Notable events include an increase in abundance of Deflandrea phosphoritica in the uppermost Chattian and the last occurrences of Chiropteridium spp., Deflandrea phosphoritica, Membranophoridium aspinatum and Ectosphaeropsis burdigalensis (in Alma-1 the last occurrences of the former three species are condensed within a single sample). Furthermore, the first occurrence of Ectosphaeropsis burdigalensis was used in Frida-1, as the casing around $970 \mathrm{~m}$ allows the use of first occurrences with caution in the studied interval.

\section{BASIN-MARGIN CORRELATION}

In order to support the dinocyst-based correlation between the basinal succession in Frida-1 and the marginal marine deposits onshore Jylland, a seismic section, running from Frida-1 to the Danish west coast, was included in the study (Fig. 6). In addition, a correlation panel of offshore wells and onshore boreholes and outcrops was established (Fig. 7). Due to the 


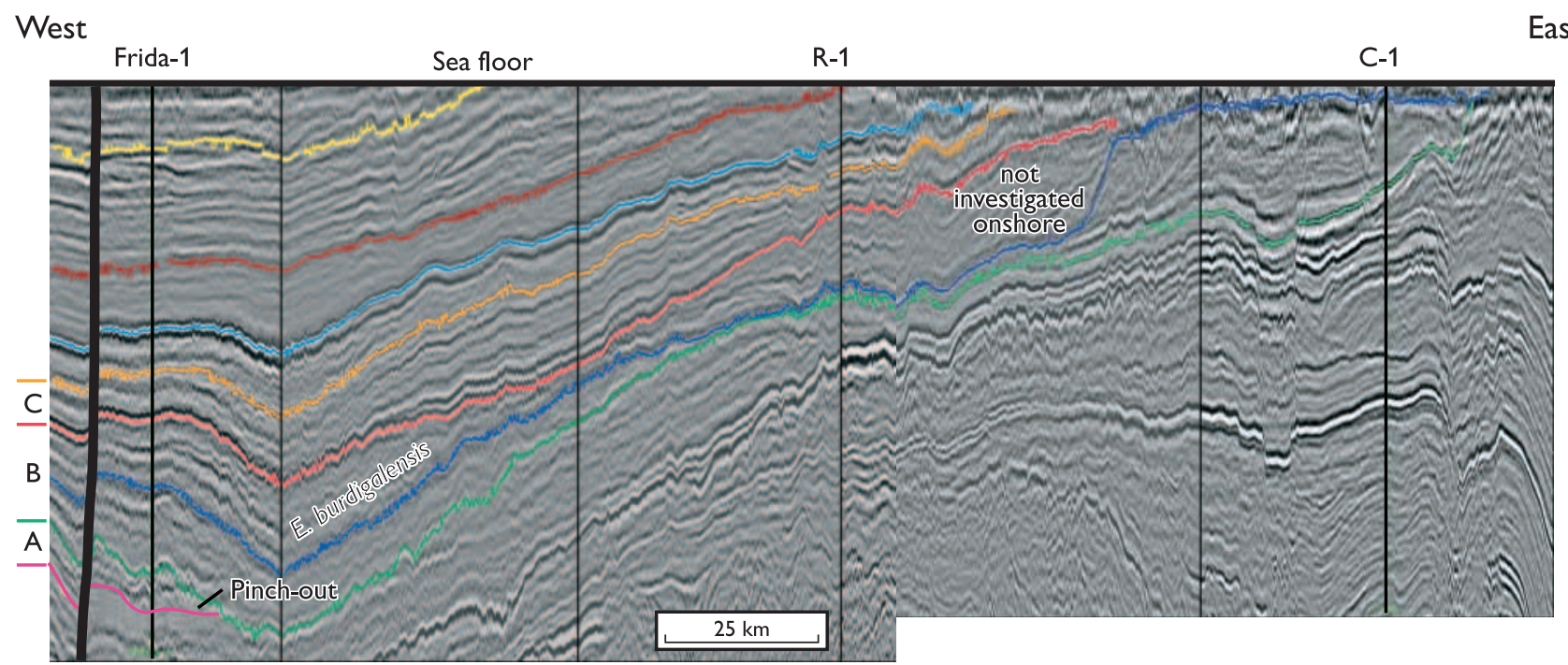

Fig. 6. East-west-striking seismic section through the offshore wells Frida-1, R-1 and C-1 (see location in Fig. 1). The sequences A to C are shown and the succession containing Ectosphaeropsis burdigalensis is indicated. Note that Sequence A is thinning towards the west. The succession containing Ectosphaeropsis burdigalensis is also pinching out towards the C-1 Well. Seismic courtesy Danpec, TGS-Nopec and Fugro.

lobal nature of the studied succession, the resulting pinch-out of delta lobes hinders direct correlation. However, the re-appearance of the pinched-out parts of the succession, as illustrated both by the seismic data and the log panel, confirms the results of the biostratigraphic study.

Correlation based on dinocysts strongly indicates that the interval corresponding to the Wetzeliella gochtii and the Distatodinium biffii Assemblages correlates with the Branden Clay onshore (Heilmann-Clausen, 1995b). This informal clay unit is preserved only in a few locations onshore, in the central and northern Jylland (Heilmann-Clausen, 1995a). This is confirmed by the seismic section (Fig. 6) and the log panel (Fig. 7) where a pinch-out of this interval can be seen just west of the Frida-1 Well (the lower part of the interval between the red and the green seismic markers).

The Deflandrea phosphoritica Assemblage comprises a c. $140 \mathrm{~m}$ thick depositional succession (the Freja Member) mainly composed of turbiditic sands (Schiøler et al., in press). Based on comparison with biostratigraphic assemblages in a marginal marine setting onshore Jylland, which show similar trends (e.g. increase in the relative abundance of Deflandrea phosphoritica and in Homotryblium spp.) (Dybkjær, 2004a, b), the succession can be correlated to a strongly condensed, glauconite-rich, clay succession onshore Jylland (the Brejning Clay; Fig. 2) which was referred to Sequence A (Rasmussen, 2004a). Due to the eastward condensed nature of Sequence A it cannot be followed directly on the seismic section (Fig. 6) or on the log correlation panel (Fig. 7). The Brejning Clay has been suggested previously to be latest Chattian in age (see Dybkjær, 2004b) and a latest Chattian age is supported strongly by the data from Frida-1, with the last occurrence of Distatodinium biffii recorded in the succession below and the first appearance of Ectosphaeropsis burdigalensis above (see Fig. 3).

The interval comprising the Homotryblium Assemblage is represented both onshore and offshore by a relatively thick succession (corresponding to the interval between the green and blue seismic horizon on Figs 6 and 7). The correlation panel for a series of onshore boreholes (Fig. 8) for this interval (referred to the lower part of Sequence B) shows an early prograding deltaic section, the Billund sand which is restricted to the north and pinches out southwards. A pinch-out towards the south and west in more basinal areas is also shown in the seismic section (Fig. 6) and in the east-west correlation panel (Fig. 7), where the lower part of Sequence B is missing in the R-1 Well.

The interval comprising the Caligodinium amiculum Assemblage in the basinal area in Frida-1, is represented by an unconformity in the marginal areas (central parts of Jylland) spanning a time interval of up to $3.5 \mathrm{Ma}$ (Dybkjær \& Rasmussen, 2000; Dybkjær, 2004b). However, in the southern part of Jylland, south of the Estrup borehole, it may be represented by the deltaic deposits of the Ribe Formation (Fig. 8). In Frida-1 this upper part of Sequence B is represented by a c. $240 \mathrm{~m}$ thick marine succession characterized by the sporadic occurrence of Caligodinium amiculum and sporadic Homotryblium tenuispinosum. Thus, there is probably no hiatus between sequences $\mathrm{B}$ and $\mathrm{C}$ in the basinal areas represented by Frida-1.

The Cordosphaeridium cantharellus Assemblage represented by the interval $1060-980 \mathrm{~m}$ in Frida-1, corresponds strongly to the assemblages recorded from Sequence C (the lower Arnum Formation) in the marginal marine deposits onshore Jylland. A direct correlation from Frida-1 to the onshore sections is, however, hampered by the presence of a Quaternary incised valley at the location of the $\mathrm{C}-1$ borehole and poor quality of the seismic data in the upper part (Figs 6,7). Severe caving of dinocysts from younger intervals in Frida-1 down to the casing around $970 \mathrm{~m}$ hinders a reliable correlation of the succession above $970 \mathrm{~m}$.

\section{DEPOSITIONAL ENVIRONMENT}

The occurrence of the genera Impagidinium and Nematosphaeropsis in Frida-1 indicates outer neritic to oceanic settings, according to Wall et al. (1977), Brinkhuis (1994) and Dale (1996). In detail, the presence of several species of Impagidinium 


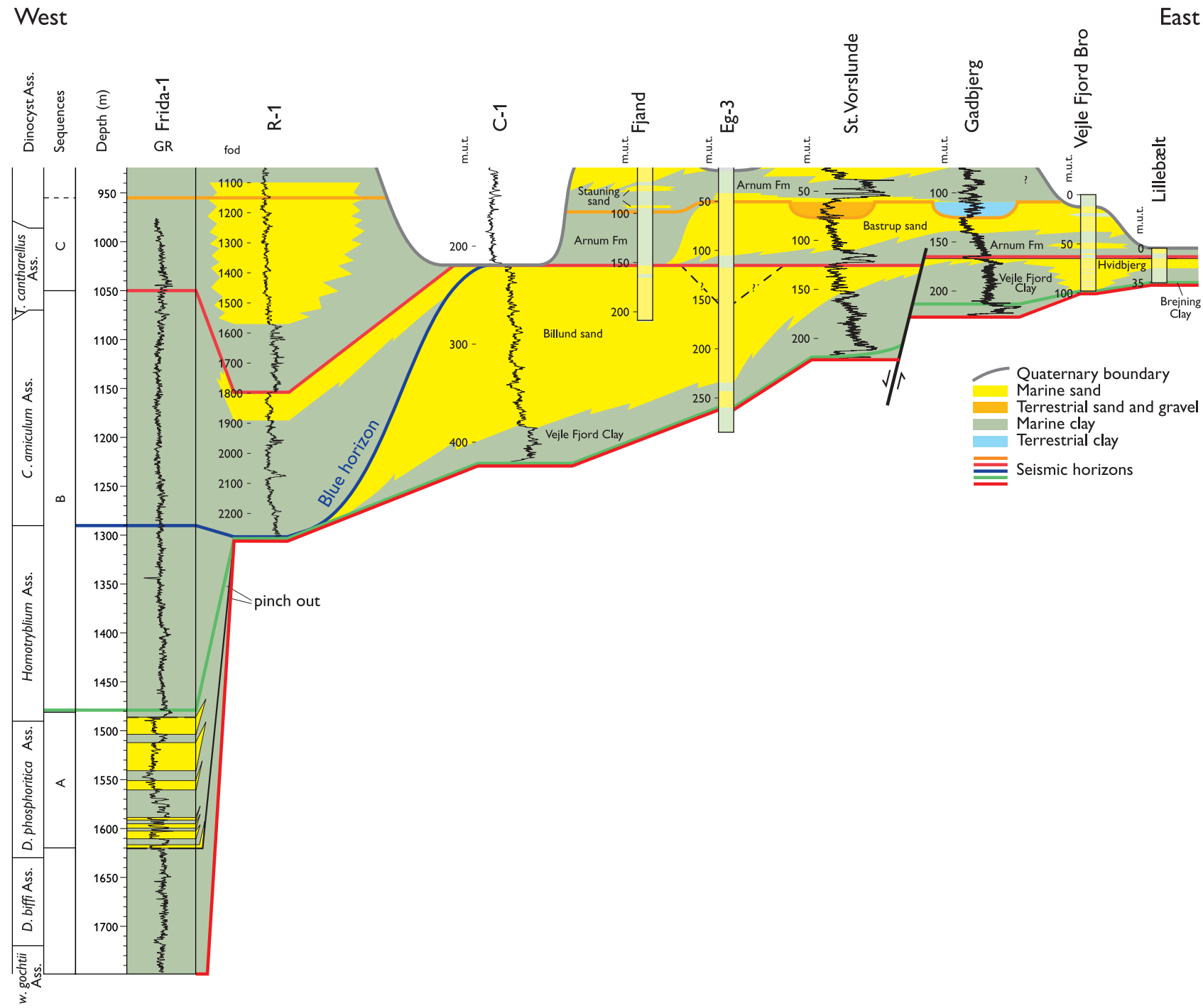

Fig. 7. Sequence stratigraphic subdivision of the Frida-1 Well and a correlation panel correlating the offshore wells Frida-1, R-1 and C-1 with the onshore boreholes Fjand, Eg-3, Store Vorslunde, Gadbjerg, Vejle Fjord Bro, and the combined borehole and outcrop section from Lillebælt. The sequence boundaries are indicated in the same colours as on the seismic section in Figure 6.

within Sequence A and the consistent occurrence of Nematosphaeropsis labyrinthus in Sequence A and the lower part of Sequence B indicate that outer neritic to oceanic conditions prevailed during deposition of this part of the studied succession. This contradicts the contemporaneous presence of genera such as Deflandrea, Glaphyrocysta and Homotryblium, which are thought to prefer inner neritic settings (or with respect to the former, nutrient-rich settings such as upwelling areas or inner neritic settings) (following Downie et al., 1971; Williams, 1977; Bradford \& Wall, 1984; Harland, 1988; Brinkhuis et al., 1992; Brinkhuis, 1994; de Verteuil \& Norris, 1996; Dybkjær, 2004b). The presence of the latter genera probably resulted from turbiditic transport from inner neritic settings by currents also responsible for the deposition of sand layers in the upper part of Sequence A.

A change in the depositional setting towards a more shallowmarine environment and closer proximity to the shoreline in the lower to middle part of Sequence B is indicated by rare
Impagidinium in Sequences B and C and by the disappearance of $N$. labyrinthus in the lower to middle part of Sequence B. This interpretation also agrees with the environmental interpretations based on the log patterns and the seismic data presented below.

\section{SEQUENCE STRATIGRAPHY OF FRIDA-1}

The sequence stratigraphic subdivision of the Upper OligoceneLower Miocene succession in Frida-1 (Figs 2, 5) follows the sequence stratigraphic subdivision of the eastern North Sea Basin suggested by Rasmussen (2004a, b) based on onshore data. The subdivision in Frida-1 is based on the correlation of dinocyst assemblages from the basinal area with the marginal marine deposits onshore, combined with seismic data (Fig. 6) and the log correlation panel (Fig. 7). The precise location of the sequence boundaries is based on changes in the geophysical log patterns (see Fig. 5). 


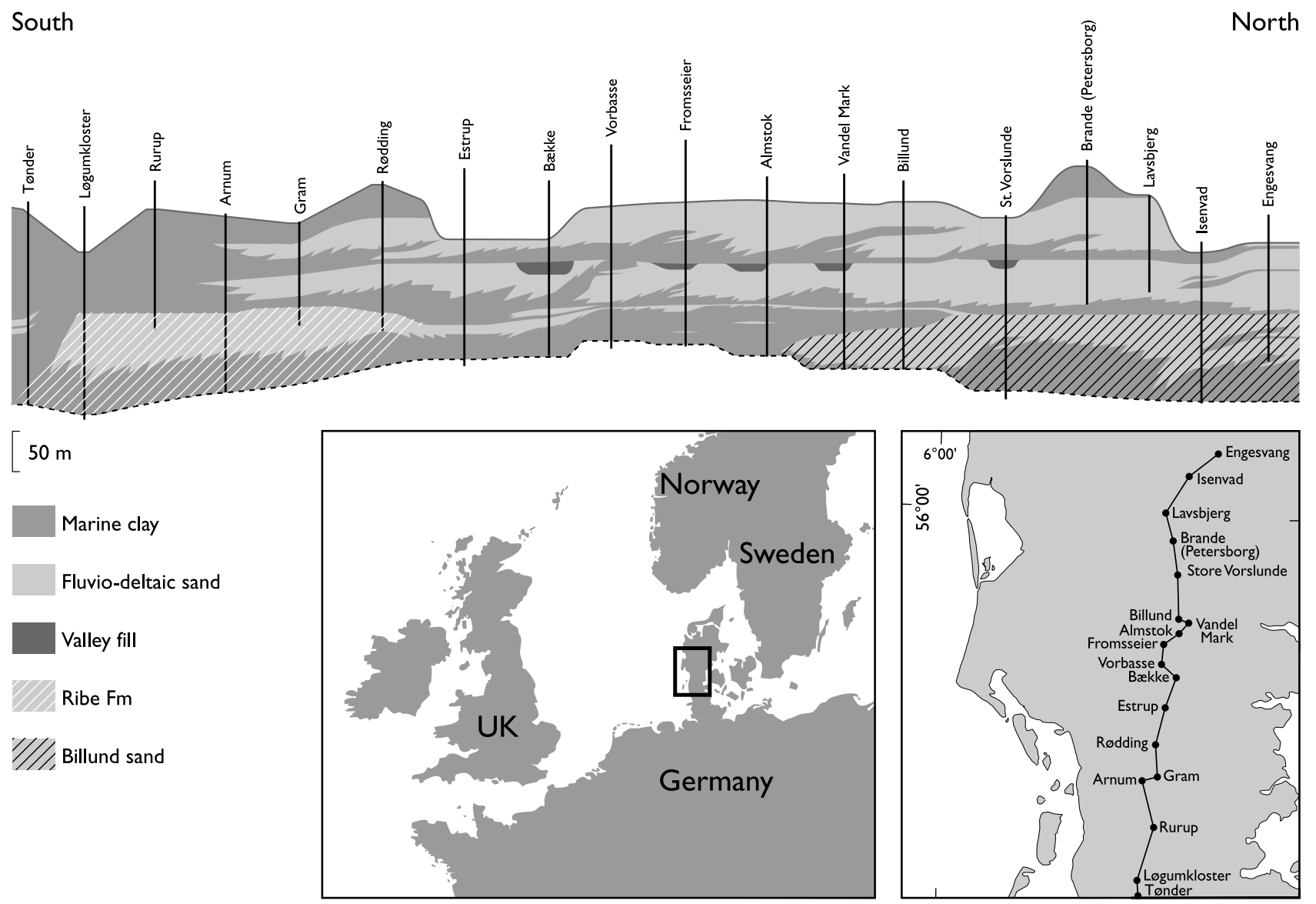

Fig. 8. Log correlation panel showing a series of boreholes from north to south in the central Jylland. Pinching out from north to south of the deltaic Billund sand is evident and the deltaic Ribe Formation is also shown. The location of the correlated boreholes is shown.

\section{Sequence A (1620-1478 m)}

The lower boundary of Sequence A should probably be placed in the interval between $1610 \mathrm{~m}$ and $1630 \mathrm{~m}$ in Frida-1, as the last occurrence of $D$. biffii at $1630 \mathrm{~m}$ probably correlates to the top of the Branden Clay onshore. The Branden Clay occurs only in the northern and central parts of Jylland due to erosion in most of Jylland. This pattern indicates that a period with distinct lowered sea-level existed during part of the Oligocene, in the time between deposition of the Branden Clay and the Brejning Clay (Michelsen et al., 1998). The gamma-low at $1620 \mathrm{~m}$ in Frida-1 (Fig. 5) suggests that the sequence boundary should be located here, at the base of the lowest turbidite sandstone of the Freja Member. The succession comprising the dinocyst assemblages $W$. gochtii and $D$. biffi thus probably represents a sequence older than Sequence A. Sequence A comprises a series of gravity deposits referred to the Freja Member (Schiøler et al., in press).

\section{Sequence B (1478-1050 m)}

In marginal marine areas the lower boundary of Sequence B is often marked by a gravel layer (Rasmussen, 2004a). The boundary occurs at the top of an acme of Deflandrea phosphoritica (Dybkjær, 2004a). In Frida-1, although representing a more basinal setting, a corresponding increase in abundance of $D$. phosphoritica was found. The uppermost sample with high abundances of $D$. phosphoritica is at $1490 \mathrm{~m}$. The lower boundary of Sequence B is therefore located at a minor gamma low at $1478 \mathrm{~m}$ (Fig. 5). The boundary can be seen as a regional seismic marker with downlap and onlap, locally with erosional features, and with conformal strata in basinal areas (Michelsen et al., 1998). The succession consists of brownish, clayey siltstone with mica interpreted as contouritic clays (Hansen et al., 2004).

\section{Sequence C (1050-955 m)}

There is probably no hiatus between sequences $\mathrm{B}$ and $\mathrm{C}$ in Frida-1, while this sequence boundary in some marginal marine areas in Central Jylland represents a hiatus of up to $3.5 \mathrm{Ma}$. (Dybkjær \& Rasmussen, 2000; Dybkjær, 2004a; Rasmussen \& Dybkjær, 2005). In the southwestern parts of Jylland the deltaic Ribe Formation was probably deposited at that time. The basinal-marginal marine correlation is further supported by the regional seismic study (Rasmussen, 2004b) and the log correlation panel (Fig. 7).

Onshore the lower boundary of Sequence $\mathrm{C}$ is located between the last occurrence of Caligodinium amiculum and the last occurrence of Thalassiphora pelagica and this is followed here, where the boundary is located at $1050 \mathrm{~m}$, at the top of an interval with an aggradational gamma log pattern. Above the boundary the gamma log shows an abrupt increase concurrent with an increase in the sonic log and a distinct peak on the 
density log, probably representing a flooding surface. On the seismic section (Fig. 6) the sequence boundary constitutes a regionally mappable marker horizon with onlap, but conformable in basinal areas. The succession consists of brownish clayey siltstones to fine-grained sandstones with mica, interpreted as marine-shelf deposits.

Severe caving in Frida-1 down to the casing around $970 \mathrm{~m}$, combined with a poor log pattern, hinders a reliable identification of the upper boundary of Sequence $\mathrm{C}$, but the dinocyst assemblage in the interval from $1060 \mathrm{~m}$ to $980 \mathrm{~m}$ in Frida-1 corresponds strongly to the assemblages recorded from Sequence C onshore. A correlation is further supported by the regional seismic study (Rasmussen, 2004b) (Fig. 6).

\section{LOCATION OF THE MI-1 GLACIATION EVENT AND THE OLIGOCENE-MIOCENE BOUNDARY}

Although correlation between the uppermost Oligocene-Lower Miocene dinocyst assemblages in the Danish onshore area and the type profile in northern Italy is not totally straightforward (see discussion in Dybkjær, 2004a), it was suggested by Rasmussen (2004b) and Rasmussen \& Dybkjær (2005) that the boundary between sequences A and B correlate to the Mi-1 glaciation event of Miller et al. (1987; 1991). It was accordingly proposed that the Oligocene-Miocene boundary be located at the sequence boundary. In addition, the boundary between sequences $\mathrm{B}$ and $\mathrm{C}$ was proposed to correlate to the Mi-1a event of Miller et al. (1991).

The results from the present study of the stratigraphically more complete succession in Frida-1 strongly support the previous datings of sequences $\mathrm{A}$ to $\mathrm{C}$ and the proposed existence of a hiatus between sequence $\mathrm{B}$ and $\mathrm{C}$ onshore (Dybkjær \& Rasmussen, 2000; Dybkjær, 2004a). The recorded last occurrence of Distatodinium biffii near the base of sequence A strongly supports a latest Chattian age for sequence A, while the last occurrences of Chiropteridium spp., Deflandrea phosphoritica and Caligodinium amiculum within sequence B strongly indicate an Aquitanian age for this sequence (Fig. 3).

A correlation between the Mi-1 glaciation event and the boundary between sequences A and B is thus supported by the present study. The location of the Oligocene-Miocene boundary in Frida-1 is likewise proposed to be located at or very near this boundary.

\section{CONCLUSION}

The Frida-1 Well, located in the basinal parts of the eastern North Sea Basin, penetrates an unusually thick $(>800 \mathrm{~m})$ and probably complete succession spanning the Upper OligoceneLower Miocene, comprising marine sediments deposited in a basinal setting.

Six dinocyst assemblages are described: the Wetzeliella gochtii Assemblage (early Chattian), the Distatodinium biffi Assemblage (Chattian), the Deflandrea phosphoritica Assemblage (latest Chattian), the Homotryblium spp. Assemblage (latest Chattian and/or early Aquitanian), the Caligodinium amiculum Assemblage (Aquitanian) and the Cordosphaeridium cantharellus Assemblage (latest Aquitanian to early Burdigalian).

A correlation, based on the dinocyst stratigraphy combined with well logs and seismic data, is proposed from the expanded and stratigraphically complete succession in Frida-1 with the more marginal settings onshore Jylland. This correlation confirms the earlier proposed ages of the onshore sequences, i.e. a latest Chattian age for Sequence A (the Brejning Clay) and of the presence of several hiati. Furthermore, the correlation made it possible to subdivide the succession in Frida-1 into sequences A-C, as defined onshore. The Mi-1 glaciation event and thus the Oligocene-Miocene boundary are proposed to correlate to the boundary between the sequences A and B.

\section{ACKNOWLEDGEMENTS}

This study was supported financially by the Danish Energy Agency through an 'Energy Research Project' (ENS J. No. 1313/00-0004) and through the Carlsberg Foundation 9901 12/20-1317. Yvonne Desezar prepared the palynological slides, Benny Munk Schark sharpened up the photoplate and Eva Melskens and Stefan Sølberg produced the drawings. Stefan Piasecki kindly commented on an early draft, while the reviews by James Powell and Henk Brinkhuis further improved the manuscript.

\section{Manuscript received 17 March 2006 Manuscript accepted 15 January 2007}

\section{REFERENCES}

Batten, D.J., Gray, J. \& Harland, R. 1999. Palaeoenvironmental significance of a monospecific assemblage of dinoflagellate cysts from the Miocene Clarkia Beds, Idaho, USA. Palaeogeography, Palaeoclimatology, Palaeoecology, 153: 161-177.

Benedek, P.N. 1972. Phytoplanktonten aus dem Mittel- und Oberoligozän von Tönisberg (Niederrheingebiet). Palaeontographica, Abteilung B, 137: 1-71.

Benedek, P.N. \& Müller, C. 1974. Nannoplankton-PhytopanktonKorrelation im Mittel- und Ober-Oligozän von NW-Deutschland. Neues Jahrbuch für Geologie und Paläontologie, Monatshefte, 7: 385-397.

Bradford, M.R. \& Wall, D.A. 1984. The distribution of recent organicwalled dinoflagellate cysts in the Persian Gulf, Gulf of Oman, and northwestern Arabian Sea. Palaeontographica, Abteilung B, 192: $16-84$.

Brinkhuis, H. 1994. Late Eocene to Early Oligocene dinoflagellate cysts from the Priabonian type-area (Northeast Italy): biostratigraphy and paleoenvironmental interpretation. Palaeogeography, Palaeoclimatology, Palaeoecology, 107: 121-163.

Brinkhuis, H., Powell, A.J. \& Zevenboom, D. 1992. High-resolution dinoflagellate cyst stratigraphy of the Oligocene/Miocene transition interval in northwest and central Italy. In: Head, M.J. \& Wrenn, J.H. (Eds), Neogene and Quaternary Dinoflagellate Cysts and Acritarchs. American Association of Stratigraphic Palynologists Foundation, Salt Lake City, 219-258.

Buchardt, B. 1978. Oxygen isotope palaeotemperatures from the North Sea area. Nature, 275: 121-123.

Chateauneuf, J.-J. 1980. Palynostratigraphie et paléoclimatologie de l'Eocène supérieur et de l'Oligocène du Bassin de Paris. Mémoires du bureau de recherces géologiques et minières (BRGM), 116: 1-360.

Coccioni, R., Montanari, A., Fornaciari, E., Rio, D. \& Zevenboom, D. 1997. Potential integrated stratigraphy of the Aquitanian to upper Burdigalian section at Santa Croce di Arcevia (NE Apennines, Italy). In: Montanari, A., Odin, G.S. \& Coccioni, R. (Eds), Miocene Stratigraphy: An Integrated Approach. Developments in Palaeontology and Stratigraphy, 15: 279-295.

Costa, L.I. 1980. Neogene dinocyst stratigraphy in the northern North Sea. Abstracts 5th International Palynological Conference, Cambridge: 92

Dale, B. 1996. Dinoflagellate cyst ecology: Modelling and geological applications. In: Jansonius, J. \& McGregor, D.C. (Eds), Palynology: 
Principles and applications. American Association of Stratigraphic Palynologists Foundation, Salt Lake City, 1249-1275.

Downie, C., Hussain, M.A. \& Williams, G.L. 1971. Dinoflagellate cysts and acritarch associations in the Paleogene of Southeast England. Geoscience and Man, 3: 29-36.

Dybkjær, K. 2004a. Dinocyst stratigraphy and palynofacies studies used for refining a sequence stratigraphic model - uppermost Oligocene to Lower Miocene Jylland, Denmark. Review of Palaeobotany and Palynology, 131: 201-249.

Dybkjær, K. 2004b. Morphological and abundance variations in Homotryblium-cyst assemblages related to depositional environments; uppermost Oligocene-Lower Miocene, Jylland, Denmark. Palaeogeography, Palaeoclimatology, Palaeoecology, 206: 41-58.

Dybkjær, K. \& Rasmussen, E.S. 2000. Palynological dating of the Oligocene - Miocene successions in the Lille Bælt area, Denmark Bulletin of the Geological Society of Denmark, 47: 87-103.

Flower, B.P., Zachos, J.C. \& Martin, E. 1997. Latest Oligocene through Early Miocene isotopic stratigraphy and deep-water paleoceanography of the western equatorial Atlantic: Sites 926 and 929. In. Shackleton, N.J., Curry, W.B., Richter, C. \& Bralower, T.J. (Eds), Proceedings of the Ocean Drilling Program, Scientific Results, 154 451-461.

Friis, H., Mikkelsen, J. \& Sandersen, P. 1998. Depositional environment of the Vejle Fjord Formation of the Upper Oligocene - Lower Miocene of Denmark: a barrier island/barrier-protected depositional complex. Sedimentary Geology, 17: 221-244.

Gerlach, E. 1961. Mikrofossilien aus dem Oligozän und Miozän Nordwestdeutschlands, unter besonderer Berücksichtigung der Hystrichosphaeren und Dinoflagellaten. Neues Jahrbuch der Geologie und Paläontologie, 112: 143-228.

Gradstein, F.M., Kristiansen, I.L., Loemo, L. \& Kaminski, M.A. 1992. Cenozoic foraminiferal and dinoflagellate cyst biostratigraphy of the central North Sea. Micropaleontology, 38 (2): 101-137.

Gradstein, F.M., Ogg, J. \& Smith, A. 2004. A Geological Time Scale. Cambridge University Press, Cambridge, 589pp.

Hansen, J.P.V., Clausen, O.R. \& Huuse, M. 2004. 3D seismic analysis reveals the origin of ambiguous erosional features at a major sequence boundary in the eastern North Sea: near top Oligocene. In: Davies, R.J., Cartwright, J.A., Stewart, S.A., Lappin, M. \& Underhill, J.R (Eds), 3D Seismic Technology: Applications to the Exploration of Sedimentary Basins. Geological Society, London, Memoirs, 29: 83-89.

Hardenbol, J., Thierry, J., Farley, T.J., de Graciansky, P.-C. \& Vail, P.R. 1998. Mesozoic and Cenozoic sequence chronostratigraphic framework of European basins. In: de Graciansky, P.-C., Hardenbol, J., Jacquin, T. \& Vail, P.R. (Eds), Mesozoic and Cenozoic sequence stratigraphy of European basins. SEPM Special Publication, 60: 3-13.

Harland, R. 1988. Dinoflagellates, their cysts and Quaternary stratigraphy. New Phytologist, 108: 111-120.

Heilmann-Clausen, C. 1995a. Palæogene aflejringer over Danskekalken. In: Nielsen, O.B. (Ed.), Danmarks geologi fra Kridt til idag. Aarhus Geokompendier, 69-114.

Heilmann-Clausen, C. 1995b. Linde-1 borehole: Paleogene dinocysts, palynofacies and stratigraphy. Report no. 18, EFP-92 project: Basin development of the Tertiary of the Central Trough with emphasis on possible hydrocarbon reservoirs. Department of Earth Sciences, Aarhus University, 18pp.

Heilmann-Clausen, C. \& Costa, L.I. 1989. Dinoflagellate Zonation of the Uppermost Paleocene? to Lower Miocene in the Würsterheide Research Well, NW Germany. Geologische Jahrbuch, A111: 431-521.

Heilmann-Clausen, C. \& Van Simaeys, S. 2005. Dinoflagellate cysts from the Middle Eocene to ?lowermost Oligocene succession in the Kysing Research Borehole, central Danish Basin. Palynology, 29: 143-204.

Herngreen, G.F.W. 1983. Dating Tertiary strata in seven boreholes in the Oldenzaal-Denekamp area (Twente), eastern Netherlands. Mededelingen Rijks geologische Dienst, 37 (3): 125-153.

Herngreen, G.F.W. 1987. Correlation between Miocene beds of the SE Netherlands and Italy based on dinoflagellate biozonation. Contributions to Tertiary and Quaternary Geology, 24 (1-2): 31-40.

Jordt, H., Faleide, J.I., Bjørlykke, K. \& Ibrahim, T. 1995. Cenozoic sequence stratigraphy of the central and northern North Sea Basin: tectonic development, sediment distribution and provenance areas. Marine and Petroleum Geology, 12: 845-879.
King, C. 1983. Cainozoic micropaleontological biostratigraphy of the North Sea. Institute of Geological Sciences Report, 82/7: 40pp.

King, C. 1989. Cenozoic of the North Sea. In: Jenkins, D.G. \& Murray, J.W. (Eds), Stratigraphical Atlas of Fossil Foraminifera, 2nd EdnEllis Horwood, Chichester, 418-489.

King, C. 1994. Biostratigraphic correlation of Late Paleocene to Oligocene sequences in the Harre borehole (north Jylland, Denmark) with those in the North Sea. Aarhus Geoscience, 1: 85-92.

Knox, R.W.O'B. \& Holloway, S. 1992. 1. Palaeogeneof the Central and Northern North Sea. In: Knox, R.W.O'B. \& Cordey, W.G. (Eds), Lithostratigraphic Nomenclature of the UK North Sea. British Geological Survey, Keyworth, Nottingham, 1-133.

Köthe, A. 1990. Paleogene Dinoflagellates from Northwest Germany. Geologische Jahrbuch, Reihe A, 118: 1-111.

Köthe, A. 1996. Dinoflagellatenzysten- und KalknannoplanktonUntersuchungen im Grenzbereich Eozän/Oligozän am Doberg bei Bünde ('Piepenhagen-Profil', Westfalen). Newsletter of Stratigraphy, 33 (3): 145-155.

Köthe, A. 2000. 8. Dinozysten der Prizierer Schichten in der Bohrung Lübtheen 27/82. In: Bülow, W.von (Ed.), Geologische Entwicklung Südwest-Mecklenburgs seit dem Ober-Oligozän. Schriftenreihe für Geowissenschaften, Berlin, 157-179.

Köthe, A. 2003a. Dinozysten aus dem Unter-Miozän (Untere Braunkohlensande, Hamburg-Ton, Obere Braunkohlensande) im Gebiet Dömitz-Lenzen (Salzstruktur Gorleben-Rambow). Brandenburgische Geowissenschaftliche Beiträge, 10 (1/2): 135-148.

Köthe, A. 2003b. Dinozysten-Zonierung im Tertiär Norddeutschlands. Revue de Paléobiologie, 22 (2): 895-923.

Köthe, A. 2004. Biostratigraphie an der Oligozän/Miozän-Grenze und im Unter-Miozän der Forschungsbohrung Wursterheide (Kalknannoplankton, Dinozysten, Norddeutschland). Senckenbergiana lethaea, 85: 201-229.

Köthe, A. 2005. Dinozysten-Untersuchungen eines untermiozänen Glaukonitsandes in der Ziegeleitongrube OLFRY/Vechta (Lower Saxony). Neues Jahrbuch für Geologie und Paläontologie, Monatshefte, 2004 (5): 257-277.

Köthe, A., Weiss, W. \& Zwirner, R. 2002. Die oligozäne und miozäne Schichtenfolge im mittleren Teil der Salzstruktur Gorleben-Rambow. Brandenburgische Geowissenschaftliche Beiträge, 9(1/2): 17-31.

Larsen, G. \& Dinesen, A. 1959. Vejle Fjord Formationen ved Brejning, Sedimenterne og foraminiferfaunaen (Oligocæn-Miocæn). Danmarks geologiske Undersøgelse, II Rakke, 82: 1-114.

Laursen, G.V. \& Kristoffersen, F.N. 1999. Detailed foraminiferal biostratigraphy of Miocene formations in Denmark. Contributions to Tertiary and Quaternary Geology, 36 (1-4): 73-107.

Londeix, L. \& Jan du Chêne, R. 1998. Burdigalian dinocyst stratigraphy of the stratotypic area (Bordeaux, France). Geobios, 30: 283-294.

Lotsch, D. 1968. Tertiär (Paläogen und Neogen). Grundriss der Geologie der Deutschen Demokratischen Republik. Band, 1: 356-379.

Louwye, S. \& Laga, P. 1998. Dinoflagellate cysts of the shallow marine Neogene succession in the Kalmhout well, northern Belgium. Bulletin of the Geological Society of Denmark, 45: 73-86.

Louwye, S., De Coninck, J. \& Verniers, J. 1999. Dinoflagellate cyst stratigraphy and depositional history of Miocene and Lower Pliocene formations in northern Belgium (southern North Sea Basin). Geologie en Mijnbouw, 78: 31-46.

Louwye, S., De Coninck, J. \& Verniers, J. 2000. Shallow marine Lower and Middle Miocene deposits at the southern margin of the North Sea Basin (northern Belgium): dinoflagellate cyst biostratigraphy and depositional history. Geological Magazine, 137 (4): 381-394.

Lund, J.J. \& Heilmann-Clausen, C. 2001. Dinoflagellate correlation between the research boreholes Nieder Ochtenhausen and Wursterheide, Miocene, NW Germany. Aardkundige Mededelingen, 11: $51-60$.

Lund, J.J., Lund-Christensen, J. \& Strauss, C. 1993. Dinoflagellate cyst biostratigraphy and palaeoenvironmental analysis in the Miocene of the RCNNS research well Nieder Ochtenhausen, NW Germany. Festschrift für Prof. Krutsch. Museum für Naturkunden Berlin, 27-37.

Maier, D. 1959. Systematik, Stratigraphie und Ökologie der coccolithophorideen, Dinoflagellaten und Hystrichosphaerideen bom Oligozän bis Pleistozän. Neues Jahrbuch für Geologie und Paläontologie, 107: 278-340. 
Martini, E. 1971. Standard Tertiary and Quaternary calceous nannoplankton zonation. In: Farinacci (Ed.), Proceedings of the 1st planktonic conference, Rome, pp. 739-785.

Michelsen, O., Thomsen, E., Danielsen, M., Heilmann-Clausen, C., Jordt, H. \& Laursen, G.V. 1998. Cenozoic sequence stratigraphy in the eastern North Sea. In: de Graciansky, P.C. \& Vail, P.R. (Eds), Mesozoic and Cenozoic Sequence Stratigraphy of European Basins. SEPM Special Publication, 60: 91-118.

Miller, K.G., Fairbanks, R.G. \& Mountain, G.S. 1987. Tertiary oxygen isotope synthesis, sea level history, and continental margin erosion. Paleoceanography, 2: 1-19.

Miller, K.G., Wright, J.D. \& Fairbanks, R.G. 1991. Unlocking the Ice House: Oligocene-Miocene oxygen isotopes, eustacy, and margin erosion. Journal of Geophysical Research, 96 (B4): 6829-6848.

Munsterman, D.K. \& Brinkhuis, H. 2004. A southern North Sea Miocene dinoflagellate cyst zonation. Netherlands Journal of Geosciences/Geologie en Mijnbouw, 83 (4): 267-285.

Paul, H.A., Xachos, J.C., Flower, B.P. \& Tripati, A. 2000. Orbitally induced climate and geochemical variability across the Oligocene/ Miocene boundary. Paleoceanography, 15: 471-485.

Powell, A.J. 1992. Dinoflagellate cysts of the Tertiary System. In: Powell, A.J. (Ed.), A Stratigraphic Index of Dinoflagellate Cysts. Chapman \& Hall, London, 155-251.

Powell, A.J. \& Brinkhuis, H. 2004a. Paleogene Time Scale - Dinoflagellate stratigraphy. In: Gradstein, F.M., Ogg, J. \& Smith, A. (Eds), A Geological Time Scale. Cambridge University Press, Cambridge, 397.

Powell, A.J. \& Brinkhuis, H. 2004b. Neogene Time Scale - Dinoflagellate stratigraphy. In: Gradstein, F.M., Ogg, J. \& Smith, A. (Eds), A Geological Time Scale. Cambridge University Press, Cambridge, 422.

Prentice, M.L. \& Matthews, R.K. 1988. Cenozoic ice volume history: Development of a composite oxygen isotope record. Geology, 16: 963-966.

Radwanski, A., Friis, H. \& Larsen, G. 1975. The Miocene HagenørBørup sequence at Lille Bælt (Denmark): its biogenic structures and depositional environment. Bulletin of the Geological Society of Denmark, 24: 229-260.

Rasmussen, E.S. 1996. Sequence stratigraphic subdivision of the Oligocene and Miocene succession in South Jutland. Bulletin of the Geological Society of Denmark, 43: 143-155.

Rasmussen, E.S. 2004a. Stratigraphy and depositional evolution of the uppermost Oligocene-Miocene succession in Denmark. Bulletin of the Geological Society of Denmark, 51: 89-109.

Rasmussen, E.S. 2004b. The interplay between true eustatic sea-level changes, tectonics and climatic changes: What is the dominating factor in sequence formation of the Upper Oligocene-Miocene succession in the eastern North Sea Basin, Denmark? Global and Planetary Change, 41: 15-30.

Rasmussen, E.S. \& Dybkjær, K. 2005. Sequence stratigraphy of the Upper Oligocene-Lower Miocene of eastern Jylland, Denmark: role of structural relief and variable sediment supply in controlling sequence development. Sedimentology, 52: 25-63.

Rasmussen, E.S., Dybkjær, K. \& Piasecki, S. 2006. Neogene fluvial and nearshore marine deposits of the Salten section, central Jylland, Denmark. Bulletin of the Geological Society of Denmark, 53: 23-37.

Schiøler, P. 2005. Dinoflagellate cysts and acritarchs from the Oligocene-Lower Miocene interval of the Alma-1X well, Danish North Sea. Journal of Micropalaeontology, 24: 1-37.

Schiøler, P., Andsbjerg, J., Clausen, O.R., Dam, G., Dybkjær, K., Hamberg, L., Heilmann-Clausen, C., Johannessen, E.P., Kristensen, L.E., Prince, I. \& Rasmussen, J.A. in press. Lithostratigraphy of the Palaeogene-Lower Neogene sediments (Rogaland to Westray Groups) in the Danish sector of the North Sea. Geological Survey of Denmark and Greenland Bulletin, 12.

Schnetler, K.I. \& Beyer, C. 1987. A Late Oligocene (Chattian B) molluscs fauna from the clay-pit of Galten Brickworks at Nørre Vissing, Jylland, Denmark. Contributions to Tertiary and Quaternary Geology, 24 (3): 193-224.
Schnetler, K.I. \& Beyer, C. 1990. A Late Oligocene (Chattian B) molluscan fauna from the coastal cliff at Mogenstrup, North of Skive, Jutland, Denmark. Contributions to Tertiary and Quaternary Geology, 27: 39-81.

Shackleton, N.J., Hall, M.A., Raffi, I., Tauxe, L. \& Zachos, J. 2000. Astronomical calibration age for the Oligocene-Miocene boundary. Geology, 28: 447-450.

Sorgenfrei, T. 1958. Molluscan assemblages from the marine middle Miocene of South Jutland and their environments. Danmarks geologiske Undersogelse, II Rakke, 79: 1-503.

Steininger, F.F., Aubry, M.P., Berggren, W.A., Biolzi, M., Borsetti, A.M., Cartlidge, J.E., Cati, F., Corfield, R., Gelati, R., Iaccarino, S., Napoleone, C., Ottner, F., Rögl, F., Roetzel, R., Spezzaferri, S., Tateo, F., Villa, G. \& Zevenboom, D. 1997. The Global Stratotype Section and Point (GSSP) for the base of the Neogene. Episodes, 20 (1): $23-28$.

Strauss, C., Lund, J.J. \& Lund-Christensen, J. 2001. Miocene Dinoflagellate Cyst Biostratigraphy of the Nieder Ochtenhausen Research Borehole (NW Germany). Geologische Jahrbuch, Reihe A, 152: 395-447.

Ulleberg, K. 1987. Foraminiferal zonation of the Danish Oligocene sediments. Bulletin of the Geological Society of Denmark, 36: 191-202.

Van Simaeys, S., De Man, E., Vandenberghe, N., Brinkhuis, H. \& Steurbaut, E. 2004. Stratigraphic and paleoenvironmental analysis of the Rupelian-Chattian transition in the type region: evidence from dinoflagellate cysts, foraminifera and calcareous nannofossils. Palaeogeography, Palaeoclimatology, Palaeoecology, 208: 31-58.

Van Simaeys, S., Munsterman, D. \& Brinkhuis, H. 2005. Oligocene dinoflagellate cyst biostratigraphy of the southern North Sea Basin. Review of Palaeobotany and Palynology, 134 (1-2): 105-128.

de Verteuil, L. \& Norris, G. 1996. Middle to upper Miocene Geonettia clineae, an opportunistic coastal embayment dinoflagellate of the Homotryblium Complex. Micropaleontology, 42 (3): 263-284.

Vejbæk, O. 1992. Geodynamic modelling of the Danish Central Trough. In: Larsen, R.M., Brekke, H., Larsen, B.T. \& Talleraas, E. (Eds), Structural and tectonic modelling and its application to petroleum geology. Norwegian Petroleum Society, Elsevier, Amsterdam, 1-17.

Wall, D., Dale, B., Lohmann, G.P. \& Smith, W.K. 1977. The environmental and climatic distribution of dinoflagellate cysts in modern marine sediments from regions in the north and south Atlantic oceans and adjacent seas. Marine Micropalaeontology, 2: 121-200.

Williams, G.L. 1977. Dinocysts: their classification, biostratigraphy and palaeoecology. In: Ramsay, A.T.S. (Ed.), Oceanic Micropalaeontology. Academic Press, London, 1231-1325.

Williams, G.L., Brinkhuis, H., Pearce, M.A., Fensome, R.A. \& Weegink, J.W. 2004. Southern Ocean and global dinoflagellate cyst events compared: Index events for the Late Cretaceous-Neogene. In: Exon, N.F., Kennett, J.P. \& Malone, M.J. (Eds), Proceedings of the Ocean Drilling Program, Scientific Results, 189: Available online at <http://www.odp.tamu.edu/publications/189_SR/VOLUME/ CHAPTERS/107.PDF $>$.

Zachos, J.C., Flower, B.P. \& Paul, H. 1997. Orbitally paced climate oscillations across the Oligocene/Miocene boundary. Nature, 388: $567-570$

Zachos, J.C., Shackleton, N.J., Revenaugh, J.S., Pälike, H. \& Flower, B.P. 2001a. Climate response to orbital forcing across the OligoceneMiocene boundary. Science, 292: 274-278.

Zachos, J.C., Pagani, M., Sloan, L.C., Thomas, E. \& Billups, K. 2001b. Trends, rhythms, and aberrations in global climate $65 \mathrm{Ma}$ to present. Science, 292: 686-693.

Zevenboom, D. 1995. Dinoflagellate cysts from the Mediterranean Late Oligocene and Miocene. $\mathrm{PhD}$ thesis. University of Utrecht, The Netherlands, 221pp.

Zevenboom, D. 1996. Late Oligocene-early Miocene dinoflagellate cysts from the Lemme-Carrosio section (NW Italy). Biostratigraphy and palaeoenvironmental interpretation. Giornale di Geologia, Serie $3 a, 58$ (1/2): 81-93.

Ziegler, P.A. 1982. Geological atlas of Western and Central Europe. Elsevier, Amsterdam, 130pp. 